\title{
MPRA
}

Munich Personal RePEc Archive

\section{FROM DIVERSIFICATION PREMIUM TO DIVERSIFICATION DISCOUNT DURING INSTITUTIONAL TRANSITIONS}

Lee, Keonbeom and Peng, Mike and Lee, Keun

2005

Online at https://mpra.ub.uni-muenchen.de/109778/

MPRA Paper No. 109778, posted 20 Sep 2021 01:42 UTC 


\title{
FROM DIVERSIFICATION PREMIUM TO DIVERSIFICATION DISCOUNT DURING INSTITUTIONAL TRANSITIONS
}

\author{
Keonbeom Lee \\ Korea Institute of Finance \\ Bankers' Building, 4-1, Myong-Dong 1-Ga, \\ Chung-Ku, Seoul, Korea 100-021 \\ Tel: (82-2) 3705-6354 / Fax: (82-2) 3705-6345 \\ kblee@kif.re.kr \\ Mike W. Peng * \\ University of Texas at Dallas, School of Management \\ Box 830688, SM 43, Richardson, TX 75083 \\ Tel: (972) 883-2714 / Fax: (972) 883-6521 \\ mikepeng@utdallas.edu
}

\author{
Keun Lee \\ Seoul National University, School of Economics \\ Shillim-dong, Seoul, Korea 151-742
}

Tel: (82-2) 880-6367 / Fax: (82-2) 877-0688

kenneth@snu.ac.kr

Forthcoming, Journal of World Business Special Issue on Korean Business

\section{* Corresponding Author}

July 2007

[Acknowledgment] This research was supported in part by the National Science Foundation (CAREER SES 0552089), UTD Provost's Distinguished Professorship, Brain Korea 21 Project, and Ohio State University CIBER and Center for East Asian Studies. Earlier versions were presented at the 8th Conference on the Theories and Practices of Securities and Financial Markets (Kaohsiung, 1999), Conference on Managing Development and Transition (Rio de Janeiro, 2001), Financial Management Association (Toronto, 2001), Seoul National University (2002), and Academy of Management (Seattle, 2003). We thank Yongsun Paik and Seung-Hyun Lee (guest editors), two reviewers, Andrew Delios, Tae-Young Kim, Klaus Meyer, and Jung Mo Yoon for helpful comments and discussions. Yi Jiang, Seong Eun Kim, and Yuanyuan Zhou provided research assistance.

//LeePengLee0707JWB.doc//7/16@HK//7/20@JN//2007//11402words// 


\title{
FROM DIVERSIFICATION PREMIUM TO DIVERSIFICATION DISCOUNT DURING INSTITUTIONAL TRANSITIONS
}

\begin{abstract}
[Abstract]
Recent development of an institution-based theory of corporate diversification has uncovered a diversification premium in emerging economies, suggesting that some business group-affiliated companies may outperform competing firms not affiliated with business groups. Is the diversification premium found in emerging economies likely to hold over time? This article extends the institutionbased theory by theoretically arguing that as institutional transitions unfold, diversification premium in emerging economies is likely to dissipate over time and eventually become a diversification discount. Then, we empirically draw on a data set from South Korea during 1984-96 involving 84 business groups and 751 group-affiliated and independent firms to substantiate this claim via a "chop shop" method. To the best of our knowledge, this represents the first study that documents the longitudinal process of how a diversification premium becomes a diversification discount during institutional transitions.
\end{abstract}


A number of studies in developed economies, primarily the United States, have documented a robust diversification discount, which suggests that firms pursuing an unrelated product diversification (conglomeration) strategy are valued less than competing firms not pursuing such a strategy (Berger \& Ofek, 1995; Lang \& Stulz, 1994; Palich, Cardinal, \& Miller, 2000). Yet, a small but expanding literature focusing on emerging economies suggests that affiliation with a diversified business group "rarely entails such a discount" (Khanna \& Rivkin, 2001: 68). Instead, based on data between the 1970s and early 1990s, studies in Chile (Khanna \& Palepu, 2000b), China (Keister, 2000; Li \& Wong, 2003; Ma, Yao, \& Xi, 2006), India (Khanna \& Palepu, 2000a; Ramaswamy, Li, \& Petitt, 2005), Indonesia (Mursitama, 2006), South Korea (Chang \& Choi, 1988; Chang \& Hong, 2000, 2002), and a variety of emerging economies (Guillen, 2000; Khanna \& Rivkin, 2001; Nachum, 2004) report a diversification premium, with some (although not all) business group-affiliated firms outperforming non-affiliated, independent firms. These findings have led to an institution-based theory of corporate diversification, centered on the institutional differences between developed and emerging economies (Peng, Lee, \& Wang, 2005; Peng, Wang, \& Jiang, 2008). It posits that conglomeration may help member firms overcome market imperfections prevalent in emerging economies (Khanna \& Palepu, 2000b; Kogut, Walker, \& Anand, 2002; Wan, 2005; Wan \& Hoskisson, 2003).

Despite the plausibility of the institution-based theory of corporate diversification, a question that immediately comes to mind is: Is the diversification premium found in emerging economies likely to hold over time? (Peng et al., 2005). The answer may be negative (Kim, Hoskisson, Tihanyi, \& Hong, 2004; Mayer \& Whittington, 2003). Since 2002, studies with more recent data from the mid to late 1990s from China (Lu \& Yao, 2006), India (Bertrand, Mehta, \& Mullainathan, 2002; Chacar \& Vissa, 2005), South Korea (Bae, Kang, \& Kim, 2002; Chang, 2003a, 2003b; Ferris, Kim, \& Kitsabunnarat, 2003; Joh, 2003), and a variety of emerging economies (Lins \& Servaes, 2002) all report a diversification discount. These newer findings thus call for a more dynamic extension of this 
theory to accommodate the change of such a premium and its likely transformation into a discount over time (Peng \& Delios, 2006). ${ }^{1}$

In response, this article extends and tests the institution-based theory of diversification premium and discount in emerging economies. Its purposes are twofold—both theoretical and empirical. First, given that the only constant in emerging economies seems to be change (Wright, Filatotchev, Hoskisson, \& Peng, 2005), we focus on the impact of institutional transitions, defined as "fundamental and comprehensive changes introduced to the formal and informal rules of the game that affect organizations as players" (Peng, 2003: 275). Theoretically, we argue that diversification premium in emerging economies is likely to dissipate over time, as market-oriented institutional transitions unfold. Second, empirically, we draw on a longitudinal data set from South Korea (thereafter Korea) between 1984 and 1996 to (1) document the existence of a diversification premium initially, (2) plot how the decline of such a premium eventually becomes a discount over time, and (3) identify how institutional transitions in capital, product, and labor markets lead to such transformation.

Overall, this article significantly departs from existing work, which usually takes a static approach (that is, conglomeration either adds or destroys value). Instead, we introduce a dynamic, longitudinal dimension, highlighting how institutional transitions turn a diversification premium into a discount. As a major emerging economy, Korea has attracted significant research attention, with two strands of findings—one documenting a diversification premium and another a diversification discount. This article builds on, connects, and extends these two contrasting strands.

\footnotetext{
${ }^{1}$ Although Japan is usually not discussed by the literature on business groups in emerging economies, the literature on Japanese keiretsu over time has evolved in a similar fashion. Earlier studies generally find that keiretsu membership tends to be beneficial—keiretsu members firms, relative to non-keiretsu firms, have lower risk and more stable performance (if not consistently higher profitability) (Lincoln, Gerlach, \& Ahmadjian, 1996). However, more recent studies report that keiretsu membership is detrimental, resulting in not only lower profitability but also higher risk (Isobe, Makino, \& Goerzen, 2006). Japan scholars argue that these changes may be largely due to the institutional transitions and intensified competition unfolding in Japan since the 1990s (Ahmadjian, 2006; Yoshikawa \& McGuire, 2008). This argument is similar to the institution-based theory of corporate diversification that has thus far focused on emerging economies.
} 
Before proceeding, one note of clarification on our level of analysis is necessary. Much of the diversification literature, based on U.S. samples, focuses on a legally independent firm (a conglomerate) and its constituent units (most of these are not legally independent firms). The Korea literature has treated a business group (chaebol) as the focal conglomerate and its affiliated firms as constituent units. A crucial difference is that the chaebol is legally "fictitious" because it does not exist as a legally independent entity, whereas affiliated firms are legally independent firms, many of which are publicly listed (Chang, 2003a; Ferris et al., 2005). Because the centralized control and resourcesharing at the group level is nevertheless real and tangible (Chang \& Hong, 2000), most Korea studies have measured group-level diversification. In this article, we first measure the group-level diversification (using the number of affiliate firms and entropy index) and then analyze the impact of this group-level diversification on affiliate-level performance.

\section{AN INSTITUTION-BASED THEORY OF CORPORATE DIVERSIFICATION}

To date, most diversification research has taken place in developed economies. The consensus among researchers since Rumelt (1974) has been that on average, unrelated product diversification (conglomeration) may destroy value, whereas related diversification may add value (Palich et al., 2000). Based on the recent Western experience, Western media and advisors often suggest that conglomerates in emerging economies destroy value and therefore should be dismantled.

However, recent studies in a variety of emerging economies report that some units affiliated with conglomerates enjoy higher profitability than independent firms (Chang \& Choi, 1988; Chang \& Hong, 2000, 2002; Guillen, 2000; Hoskisson, Cannella, Tihanyi, \& Faraci, 2004; Kedia, Mukherjee, \& Lahiri, 2006; Keister, 2000; Khanna \& Palepu, 2000a, 2000b; Khanna \& Rivkin, 2001; Li \& Wong, 2003; Ma et al., 2006; Lu \& Yao, 2006; Nachum, 2004; Toulan, 2002). Overall, there seems to be a discernible performance premium associated with some (although not all) firms' conglomeration strategy in emerging economies. Such recent research thus has led to a new, institution-based theory, 
suggesting that diversification strategies are, at least in part, driven by the institutional frameworks governing strategic choices (Peng et al., 2005, 2008; Wan \& Hoskisson, 2003).

The institution-based theory suggests that the institutional frameworks governing emerging economies are characterized by underdeveloped capital, product, and labor markets (Khanna, Palepu, \& Sinha, 2005; Peng \& Heath, 1996). Perhaps the most significant differences between developed and emerging economies lie in capital markets, which may have "a positive, first-order relationship" with economic development (Levine, 1997: 688; see also Fauver, Houston, \& Natanjo, 2003; La Porta et al., 1997). However, capital markets in developed economies have not always been sophisticated. Researchers in fact have documented "a dramatic reversal in [U.S.] investor sentiment toward diversification-positive in the 1960s, neutral in the 1970s, and negative in the 1980s" (Matsusaka, 1993: 358). Relative to the period since the 1980s, capital markets in developed economies before the 1970 s were less sophisticated. As a result, conglomerates at that time were perceived ex ante by capital markets to have an advantage in allocating capital internally. Over time, however, as capital markets develop, this conglomerate advantage has become less important in developed economies (Liebeskind, 2000).

This line of reasoning suggests that the level of capital markets development in emerging economies in the 1980s and 1990s might be similar to that in developed economies in the 1960s (or even before), thus resulting in a conglomerate advantage (Nachum, 2004). While insightful, these static arguments, comparing the 1990s emerging economies and the 1960s developed economies, need to be extended dynamically. We will take on this challenge in the next two sections.

\section{INSTITUTIONAL FRAMEWORKS AND DIVERSIFICATION STRATEGIES}

Although institutions as "the rules of the game in a society" powerfully shape strategic choices (North, 1990; Peng, 2003), institutions also change in character and potency over time. In turn, firms need to adapt to new institutional realities. Otherwise, firms failing to adapt may find their previous fit with old institutional requirements to be unable to ensure continued legitimacy and even survival. This 
argument is especially likely to be borne out in emerging economies, which in recent years have unleashed a wide variety of institutional transitions calling for strategic changes (Wright et al., 2005).

Recent work suggests that a conglomeration strategy cannot be argued to be either uniformly beneficial or uniformly costly without a specification of the institutional contingencies (Peng et al., 2005; Peng \& Delios, 2006). Given that a conglomeration strategy inherently carries both costs and benefits, the key is to identify the institutional contingencies under which costs are likely to outweigh benefits (and vice versa) (Hill, Hitt, \& Hoskisson, 1992; Peng et al., 2005). One key contingency is the relative costs and benefits of external versus internal capital markets over time.

A basic proposition of the institution-based theory of corporate diversification is that relative to developed economies, greater imperfections in the external capital, product, and labor markets in emerging economies, which are called "institutional voids" (Khanna \& Palepu, 2000b; Lee \& Oh, 2007; Ma et al., 2006), would make internalization through a conglomeration strategy more attractive. In a nutshell, external markets development and conglomeration may substitute each other (Peng et al., 2005). Specifically, internal capital markets brought by conglomeration are "most valuable among firms and economies where it is costly to obtain external capital” (Fauver et al., 2003: 136). In addition, Khanna and Palepu (2000b: 269) argue that researchers also need to probe into conglomeration's role in combating product and labor markets imperfections. Thus:

\section{Hypothesis 1: During a period when external capital, product, and labor markets are less} transparent, open, and competitive, there is a diversification premium.

While insightful, this theory needs to confront both (1) the theoretical possibility that institutional transitions may change the relative costs and benefits of conglomeration (Peng, 2003; Peng et al., 2005) and (2) the empirical findings that under certain institutional conditions there may be a diversification discount in emerging economies (Bae et al., 2002; Bertrand et al., 2003; Chang, 2003; Ferris et al., 2003; Joh, 2003). The next section therefore develops this theory further. 


\section{FROM DIVERSIFICATION PREMIUM TO DIVERSIFICATION DISCOUNT}

To the extent that the institution-based theory centers on the impact of institutional frameworks on corporate strategies (Khanna \& Palepu, 2000b; Peng, 2003; Peng et al., 2008; Wan \& Hoskisson, 2003), it seems imperative that changes in the institutional frameworks would alter the costs and benefits of conglomeration (Peng et al., 2005). Guillen (2000) argues that it is the protectionist policies maintained by the state that has led to the rise of conglomerates in emerging economies. Conglomerates can leverage their non-industry-specific connections to enter multiple industries by obtaining licenses from the state, arranging financial packages, securing technology, hiring and training labor forces, and establishing supply and distribution channels. Such a generic, non-industryspecific capability embodies an ability to leverage relationships with a variety of crucial institutions (e.g., government agencies, financial institutions). Moreover, this capability is difficult to trade because it is embodied in a conglomerate's knowledge, contacts, and routines. Therefore, such a capability "encourages those who possess it to diversify across industries rather than become specialists in one industry or product line" (Guillen, 2000: 365; see also Chung, 2006).

However, when the state embraces market-opening, liberalization policies, the scope and size of conglomerates may become a liability rather than a strength (Chang, 2003a; Guillen, 2000;

Hoskisson et al., 2004). In particular, when institutional transitions result in a more open international trade and investment regime, competitive pressures from both foreign multinationals and nondiversified domestic firms may intensify (Toulan, 2002). Also, capital markets may become better regulated and more transparent and open, and product and labor markets more competitive. As long as the state no longer provides preferential resources to conglomerates, conglomeration's benefits of overcoming imperfections in capital, product, and labor markets prevalent in emerging economies may decrease (Guillen, 2000; Kim et al., 2004). Overall, diversification premium may decline, as reported by Khanna and Palepu (2000b) in Chile and Chang and Hong (2000) in Korea. Therefore:

Hypothesis 2: During a period with generally less transparency, openness, and competition (as featured in H1), when external capital, product, and labor markets gradually become more transparent, open, and competitive, there is a reduction in diversification premium over time. 
An implicit assumption underpinning $\mathrm{H} 1$ and $\mathrm{H} 2$ is that organizational size and complexity remain the same and that the only differences are institutional transitions. If this assumption is relaxed and organizational size and complexity increase, it is likely that institutional transitions may further reduce diversification premium. As the size and complexity of conglomerates increase, previously optimal, internal allocation of capital is likely to be replaced by inefficient allocation of capital (Hill et al., 1992; Lee \& Lee, 2002). Increasing organizational size and complexity may be especially problematic for firms going through environmental uncertainty associated with institutional transitions. Jones and Hill (1988: 166) argue that "Increasing environmental turbulence will increase complexity, instability, and therefore bureaucratic costs." As a result, conglomerates, in theory at least, may have an incentive to downsize and/or downscope when confronting rising environmental uncertainty. Conversely, we argue that when facing institutional transitions, (1) conglomerates that are unable or unwilling to reduce their scope and (2) even worse, conglomerates that increase their organizational size and complexity are likely to see their diversification premium dissipate.

Further, if diversification premium is sufficiently reduced, it may turn into a diversification discount. This can be explained by the theory of strategic change, which centers on an organization's continuous alignment with its external environment (Peng, 2003; Rajagopalan \& Spreitzer, 1996). When the institutional environment facilitating a diversification premium changes to become to a setting whereby conglomeration is increasingly difficult to add value, a conglomeration strategy may need to be adjusted and product scope may need to be downsized/downscoped. Such downsizing/downscoping calls for a reduction in organizational size and complexity in order to achieve a better fit with the changed environment. However, conglomerates that move against the trend and increase (instead of decrease) their size and complexity are likely to suffer from a misalignment between its strategy and environment (Rajagopalan \& Spreitzer, 1996). Because of such a "mismatch" between the changing environment and the inertia-laden conglomeration strategy (Chang, 2003a: 37), the previous diversification premium may be gradually replaced by a diversification discount (Kim et al., 2004). H3, therefore, is essentially a stronger form of H2 (Chang, 2003b: 241-2), whose assumption on a constant level of organizational size and complexity is relaxed. 
Hypothesis 3: During a period with generally less transparency, openness, and competition (as featured in H1), when (1) external capital, product, and labor markets become more transparent, open, and competitive and (2) organizational size and complexity increase, there is a diversification discount over time.

\section{METHODOLOGY}

\section{Institutional Transitions in a Research Laboratory}

Institutional transitions in South Korea during the 1980s and the 1990s present an ideal "research laboratory" to test our hypotheses. The Korean economy is dominated by conglomerate business groups known as the chaebols, which contributed approximately $40 \%$ of its total output as of 1996 (Chang, 2003a; Ungson, Steers, \& Park, 1997). A chaebol is defined by the Korean Fair Trade Commission (KFTC) as "a group of companies of which more than $30 \%$ of shares are owned by the group's controlling shareholder and its affiliated companies" (Bae et al., 2002: 2699).

Since the 1980s, transitions in product and labor markets are significant. First, Korea's eagerness to join the OECD prior to its accession in 1996 resulted in external pressures to open the economy (Lee, Lee, \& Lee, 2002). The government gradually removed import restrictions, with the percentage of unrestricted import items rising from less than $85 \%$ in 1984 to almost $100 \%$ in 1996 (Table 1). As a result, Korean firms have to compete with foreign competitors in previously closed product markets at home, resulting in shrinking profit margins. ${ }^{2}$ Second, labor markets experienced strong upward surge for wages, as workers in the democratic era since the late 1980s became (1) more assertive, (2) more qualified (as evidenced, for example, by the rising percentage of secondary school enrollment from $86.7 \%$ in 1984 to $98.7 \%$ in 1996 -Table 1), and (3) hence more costly.

\section{[ Insert Table 1 about here ]}

\footnotetext{
${ }^{2}$ Many Korean firms also aggressively export and engage in foreign direct investment (Ungson et al., 1997). However, in general, export sales have been less profitable than domestic sales in Korea, and in some cases not profitable at all. A primary reason is that the historically protectionist policy imposed by the government has resulted in domestic prices to be higher than international prices, effectively subsidizing export sales.
} 
While institutional transitions in product and labor markets are tremendous, nowhere are the transitions more significant than capital markets. The OECD requirement of capital account opening as a condition of membership and the government's eagerness to comply made Korea's post-1993 financial markets opening one of the most rapid and most comprehensive among emerging economies (Lee et al., 2002). Overall, the number of listed companies increased 126\% (from 336 in 1984 to 760 in 1996), ${ }^{3}$ and the stock market capitalization/GDP ratio experienced a whopping $782 \%$ increase (from $3.3 \%$ in 1984 to $29.1 \%$ in 1996). The number of securities analysis companies increased from 25 in 1986 to 38 in 1996 (a 52\% increase). While capital markets were better developed, uncertainty was also heightened, as evidenced by the increase in the daily stock price fluctuation band ${ }^{4}$ allowed by the authorities, from $2.9 \%$ in 1984 to $8 \%$ in 1996 . In addition, foreign investors, not allowed to own Korean equity prior to 1991, were able to rapidly expand the ceiling of their Korean shareholdings, from $10 \%$ in 1992 to $20 \%$ by the end of 1996 , adding new performance pressures on Korea firms. $^{5}$

Both the liberalization of capital markets and transitions of product and labor markets significantly added to the environmental uncertainty that chaebols confront. Yet, instead of downsizing, the chaebols, especially the top 30 groups, continued their expansion, as exemplified by the increasing number of listed and non-listed affiliated firms (from 16.7 per group in 1987 to 22.3 in 1996, a 34\% increase). Among these affiliates, the average number of listed affiliates grew from 3.29 per group in 1984 to 5.25 in 1996, representing a 60\% increase (Table 1). In particular, chaebols undertook "an aggressive investment drive" during 1994-96 (IMF, 1997: 1; see also Chang, 2003a:

\footnotetext{
${ }^{3}$ The government pushed many chaebols to list some of their member firms (Chang, 2003a).

${ }^{4}$ This refers to the maximum range of stock price fluctuation, beyond which the securities authorities will intervene on behalf of the government (usually by suspending trading of certain stocks).

${ }^{5}$ The transitions during and after the 1997 financial crisis were even more rapid. The maximum ceiling for foreign equity holding in Korean firms was raised four times during 1997. Eventually in 1998, the ceiling was abolished, effectively allowing for direct foreign acquisition of $100 \%$ equity of Korean firms. By 2005 , foreigners owned $42 \%$ equity of listed firms in Korea (Economist, 2005).
} 
82-83). The upshot is that chaebols' size and complexity expanded significantly during the period under study (1984-96), peaking during the very last (sub)period of 1994-96.

In summary, the institutional transitions in Korea during the 1980s and the 1990s have all the necessary ingredients to test our hypotheses. In addition, another justification to focus on Korea is that it probably is the most extensively studied emerging economy in terms of diversification premium and discount, thus allowing for comparison with previous findings. Starting with Chang and Choi (1988), several studies document a diversification premium (Chang \& Hong, 2000, 2002; Guillen, 2000; Khanna \& Rivkin, 2001). In contrast, more recent studies find a diversification discount (Bae et al., 2002; Chang, 2003a, 2003b; Ferris et al., 2003; Joh, 2003; Lins \& Servaes, 2002). None of these studies, however, has theorized and reported the existence of both diversification premium and discount and plotted their transformation. This will be the challenge we take on in this study.

\section{A Modified "Chop Shop" Method}

We employ a modified "chop shop" method adjusted to Korean realities, which is a popular approach in finance (Berger \& Ofek, 1995; Ferris et al., 2003; Lang \& Stulz, 1994). One reason that we adopt this method, which is under-utilized in strategy, is that we want to make our results comparable with the existing literature adopting the same method. ${ }^{6}$ Using the "chop shop" method one can estimate the value of the firm by "chopping" it up via an examination of the value of its divisions. The value of conglomerate divisions can be reasonably approximated by the average value of stand-alone firms in the same industry in which these divisions compete. The sum of the imputed value of a conglomerate's divisions thus estimates the value of the conglomerate as if all its divisions were stand-alone firms. Then, the excess value of a conglomerate is defined by the natural log value of the ratio of its actual value to its imputed value. A positive excess value suggests that diversification enhances the value of divisions beyond that of their stand-alone counterparts-in other words, a diversification premium. Conversely, a negative excess value implies a diversification discount.

\footnotetext{
${ }^{6}$ The "chop shop" method, while popular in finance, is not perfect. See recent criticisms by Graham, Lemmon, and Wolf (2002) and Whited (2001).
} 
The difference between our method and the traditional "chop shop" method lies in the calculation of imputed value. While the traditional "chop shop" method treats a conglomerate as a firm and its divisions, we focus on a conglomerate as a group of firms (chaebol or business group) and its legally independent, affiliated member firms. With centralized integration and control, a Korean business group (with member firms) has typically taken on the characteristics of a Western conglomerate firm (with divisions). As indicated earlier, all previous Korea studies (cited above) have treated business groups and their group-affiliated member firms as if they were "conglomerate firms" and their "divisions" in the West, respectively. We have followed these precedents.

Specifically, our imputed value of a group-affiliated firm is a value of its accounting item (sales or earnings before income taxes [EBIT]) multiplied by the ratio of a value of total capital (sum of the market value of equity and the book value of debt) to this item for the median stand-alone firm in the same industry. It has the following property:

$$
I V_{g r}=A I_{g r} *(V / A I)_{s a}
$$

where $I V_{g r} \quad=$ imputed value of a group-affiliated firm in the industry $i$ as a stand-alone firm

$A I_{g r} \quad=$ a value of the accounting item of a group-affiliated firm (sales or EBIT)

$(V / A I)_{s a}=$ ratio of a value of total capital to an accounting item (sales or EBIT) for the median stand-alone firm in industry $i$.

Then, the excess value of a chaebol-affiliated firm is defined by the log value of the ratio of actual to imputed value of the firm as follows:

$$
\text { Excess value }=\log \left(V_{g r} / I V_{g r}\right)
$$

We apply our method to all publicly listed, non-financial firms during 1984-96, by drawing on a database amassed by the Korean Listed Companies Association (e.g., Bae et al., 2002).

\section{Variables}

Dependent variables. We follow Berger and Ofek (1995) to focus on two accounting items: sales and EBIT. We first calculate the industry median (mean) of capital-to-sales and capital-to-EBIT ratios for all stand-alone firms in each industry. Capital is the sum of the market value of equity and 
the book value of debt. Then, the imputed value of a group-affiliated firm is obtained by multiplying this median (mean) ratio to the actual sales or EBIT. Thus, the imputed value represents the hypothetical value of a group-affiliated firm, as if it operated as an average stand-alone firm. Industry classification is based on the Korean Standard Industrial Classification (KSIC) two-digit code. Each industry is supposed to include at least three stand-alone firms every year, and industry dummies are included to control for industry-specific effects. ${ }^{7}$

Diversification measures. There is some controversy regarding the appropriateness of different measures of diversification (Robins \& Wiersema, 2003). As a result, we employ three measures of diversification (one dummy and two continuous), which would provide stronger conclusions if they lead to similar findings. First, a dummy variable is created for firms affiliated with business groups (Ferris et al., 2003; Khanna \& Palepu, 2000b). We first examine the 30 largest chaebol groups officially designated by the KFTC in terms of total assets since 1987 . Because there are small changes from year to year, a total of 38 groups are designated more than once. For all pre1987 groups and medium and small sized groups (not in the top 30) since 1987, we rely on a report by Daeyu Securities. Companies are considered "related" and thus as affiliates of chaebols when the same person or relatives are the controlling shareholders or when one listed firm holds a substantial ownership (usually the largest) stake in other listed firms.

A total of 84 business groups have been identified. Overall, our sample includes a total of 751 firms (305 group-affiliated firms and 446 unaffiliated firms). Then the maximum number of companyyears would be 9,763 (13 years x 751 firms). Because some firms stopped being listed and some went bankrupt in addition to reporting and data problems in the database, we end up with 6,025 company-years of excess values using the sales multiplier and 5,281 company-years of excess values using the EBIT multiplier.

\footnotetext{
${ }^{7}$ When there exist less than three stand-alone companies in an industry, we follow Fauver et al. (2003) to use the broader industrial classification based on the input-output tables compiled by the Bank of Korea. To minimize the potential impact of outliers, we follow Berger and Ofek (1995) and Fauver et al. (2003) to exclude 80 and 98 extreme cases for the sales and EBIT multipliers, respectively, whose actual value is more than four times or less than one-fourth of the imputed value.
} 
Panel A of Table 2 provides basic statistics. Consistent with Ferris et al. (2003), the standalone and group-affiliated firms are significantly different. Group-affiliated firms are much bigger, and invest and borrow more. The tax-to-sales ratios of group-affiliated firms are lower than those of standalone firms, which suggest that group-affiliated firms are likely to take advantage of tax-deductible interest payments by taking on more debt. ${ }^{8}$

\section{[ Insert Table 2 about here ]}

Given the dichotomous nature of the group affiliation dummy, we also employ two continuous measures of diversification. We first measure the number of listed affiliated firms for each chaebol group. Since each affiliated firm within a chaebol usually specializes in one industry, the number of affiliates is indicative of the scope of group-level diversification. We then calculate the entropy index (Hill et al., 1992; Palepu, 1985) using the sales of all affiliated firms for each chaebol. The entropy measure of total diversification is defined as follows: DT $=\Sigma_{i} S_{i}{ }^{*} \ln \left(1 / S_{i}\right)$ where $S_{i}$ is the share of an affiliated company (i) among total sales of the group. Overall, these two continuous measures attempt to capture (albeit imperfectly) the construct of organizational size and complexity highlighted in $\mathrm{H} 3$.

Institutional variables. Five previously used, exploratory variables aiming to capture some aspects of institutional transitions in capital, product, and labor markets are selected. For capital markets, we select the stock market capitalization/GDP ratio, which is the most widely used indicator of financial markets development (Levine, 1997) and employed in related previous work (Guillen, 2000; Khanna \& Palepu, 2000b). Since capital markets encompass markets other than stock markets, we follow King and Levine (1993) to include the corporate bond value/GDP ratio and private sector credit/GDP ratio as proxies for bond markets and credit markets, respectively. All these three measures of capital markets development showed strong growth during 1984-96 (see Table 1).

For changes in product markets, in the spirit of Guillen (2000), we use the percentage of import categories not subject to import restrictions, which increased to $99.3 \%$ by 1996 (see Table 1).

\footnotetext{
${ }^{8}$ Chaebol affiliate firms may have an incentive to take on more debt, because a high level of leverage may add value by reducing tax obligations on interest payments.
} 
The upshot is that more commodities (especially intermediate products) are now freely available in product markets with little or no import duty distortion, thus reducing the need for chaebols to make them in-house. For labor markets changes, following Khanna and Palepu (2000b: 272), Levine (1997: 707), and Wan and Hoskisson (2003: 34), we measure the percentage of students entering secondary schools among primary school graduates to document the rising levels of qualifications and hence costs of the participants of labor markets (Table 1). The intuition behind these variables is that they add to the environmental uncertainty in product and labor markets.

Overall, given the complexity and multidimensionality of institutional transitions, these previously used exploratory variables obviously represent an incomplete set. However, since all of them have been successfully employed elsewhere, it would be interesting to assess their impact as one "package" of institutional transitions on diversification premium/discount in a new setting.

Control variables. Five widely used control variables are included. First, the log of sales controls the firm size effect (Chang, 2003b). Second, the EBIT/sales ratio serves as a proxy for profitability (Berger \& Ofek, 1995). Third, the capital expenditure/sales ratio provides a measure of growth opportunities (Berger \& Ofek, 1995). Fourth, leverage is measured by the debt/equity ratio (Chang \& Hong, 2000). Finally, firm age is controlled (Guillen, 2002).

\section{Analytical Procedures}

A total of five analyses are undertaken. First, we conduct bivariate tests to compare excess values, using both sales and EBIT multipliers. Second, we run the following regression:

Excess value at the firm level $=\alpha+\beta_{1}{ }^{*}$ diversification measure at the group level $+\beta_{2}$ * controls at the firm level + error term

This cross-level specification is driven by the conceptual need to focus on the firm level per the "chop shop" method-the total value of any group (conglomerate) is inferred by the aggregate value of its constituent units (affiliate firms in this case) (see Ferris et al., 2003). In addition, this approach is also necessitated by both the well-known fact that each chaebol group closely controls its affiliate firms and the practical difficulty of directly measuring group-level excess value. Note that groups are not listed and legally speaking, groups do not even exist and are "fictitious" (Chang, 2003a). 
Third, we follow Khanna and Palepu (2000b: 279) to use time as a general proxy for incremental institutional transitions. In addition, we add an interaction item between the diversification measure and the time variable to regression (3) above.

Fourth, although the general time line may be indicative of institutional transitions, according to Chang and Hong (2000: 444; 2002: 270) and Khanna and Palepu (2000b: 276), there may be distinct differences across different time periods. Therefore, we divide the 13-year period into four equal periods (four years in the first period, 1984-87 and three years each in three later periods, 1988-90, 1991-93, and 1994-96), and run regression (3) above for each period and also for each year to check the sensitivity of the results on how we divide the whole period.

Finally, in order to identify the impact of particular institutional transitions, we introduce several specific institutional variables as follows:

Excess value at the firm level $=\alpha+\beta_{1}$ * diversification measure at the group level $+\beta_{2}$ * institutional variables $+\beta_{3}{ }^{*}$ institutional variables ${ }^{*}$ diversification at the group level $+\beta_{4}$ * controls + error term

\section{FINDINGS}

Panel B of Table 2 reports the excess value estimates for the whole sample during the 13-year period (1984-96). The positive differences in median and mean excess values between groupaffiliated and stand-alone firms indicate the existence of diversification premium, thus supporting $\mathrm{H} 1$. In both estimations using the sales and EBIT multipliers, group-affiliated firms enjoy higher firm values, although the differences turn out to be significant only in the case of the EBIT multiplier.

Having found an overall diversification premium, we proceed to explore its determinants based on descriptive statistics reported in Table 3. The results from pooled regression models in Table 4 demonstrate the positive value premium of group-affiliated firms based on the group affiliation dummy as the diversification measure, as shown by the significantly positive coefficients in Models 2 and 6 . 
The premium for the sales multiplier is approximately $4.7 \%(p<0.001)$ and that for the EBIT multiplier is about $5.3 \%(p<0.001)$. These results again support $\mathrm{H} 1 .^{9}$

\section{[ Insert Table 3 and Table 4 about here ]}

Then we move on to investigate whether such premium changes over time. In Table 4, this is done by first adding the time variable in Models 3 and 7 and then adding an interaction item between the group affiliation dummy and the time variable in Models 4 and 8 . The significantly negative interaction item suggests that the premium captured by Models 2 and 4 declines approximately $1.8 \%$ $(p<0.001)$ per year for the sales multiplier and $1.6 \%(p<0.001)$ per year for the EBIT multiplier, thus supporting H2. These results are consistent with Khanna and Palepu's (2000b: 279) findings in Chile.

Next, we move on to divide the 13 years into four equal periods, and run regression (3) as done for Models 2 and 6 in Table 4. Table 5 reports the period-by-period trend of the diversification effect using the group affiliation dummy. In both Panels A and B using the sales and EBIT multipliers, respectively, the decline of the group affiliation effect during the first three periods is clear. Then during the last, 1994-96 period, the previously significantly positive coefficient for the group affiliation dummy on the sales multiplier has changed to a significantly negative one (Model 4: $\beta=-0.055, p<$ 0.05). This finding, thus, demonstrates the existence of a diversification discount and again supports H2. During the same period, the same effect on the EBIT multiplier has also changed from a positive to a negative sign (Model $8: \beta=-0.024$ ). Although this negative coefficient is statistically insignificant from zero, it is no longer significantly above zero as found in Models 5-7, thus pointing out the disappearance of the diversification premium. Ferris et al. (2003) also find the similar value loss (or discount) for chaebol firms but do not deal with the possibility that there might have been a premium during an earlier period such as the 1980s.

\section{[ Insert Table 5 about here ]}

In Tables 6-8, we repeat the same procedures, using two continuous measures of diversification which are also proxies for organizational complexity to test H3. Table 6 replicates Table

\footnotetext{
${ }^{9}$ These results are checked for, and found to be free from, the possible impact of serial correlation associated with using the pooled data and also of the heteroskedasticity (results are available upon request).
} 
4, and the results are similar. For the pooled sample using both sales and EBIT multipliers, the number of affiliates in Models 1 and 4 suggests a $0.8-1.2 \%$ premium (smaller than the magnitude reported in Table 4), and the entropy index in Models 7 and 10 indicates a 4-5\% premium (about the same as in Table 4). These findings again support H1. Further, the significantly negative interaction between the diversification measures and the time variable is supportive of $\mathrm{H} 2$ and $\mathrm{H} 3$, indicating an annual decline of the premium of $0.4 \%$ using the number of affiliates (Models 3 and 6 ) and 1.6-1.8\% using the entropy measure (Models 9 and 12). Tables 7 and 8 replicate Table 5 . The results are corroborative, not only indicating a decline of the diversification premium over time, but also the emergence of a diversification discount during the last period (1994-96). Similar to the findings on chaebols' value loss during $1992-95$ by Ferris et al. (2003: 270), our findings again support H3. Overall, despite some relatively minor differences, taken together (shown in Figure 1 based on the coefficients of the three diversification measures in Tables 5, 7, and 8), the findings converge to strongly support $\mathrm{H} 2$ and $\mathrm{H} 3$.

\section{[ Insert Tables 6, 7, and 8 and Figure 1 about here ]}

Finally, in Table 9, we replace the time trend used in Table 4 with a time series of each of the five exploratory institutional variables. Following Khanna and Palepu (2000b: 279), this procedure enables us to identify what particular institutional transitions drives support for $\mathrm{H} 2$ and $\mathrm{H} 3$. With finergrained details, the findings corroborate those reported earlier, in that the diversification premium associated with the group affiliation dummy declines significantly as institutional transitions in capital, product, and labor markets unfold. Overall, these results, again, strongly support $\mathrm{H} 2$ and $\mathrm{H} 3{ }^{10}$

\section{[ Insert Table 9 about here ]}

In addition, we have conducted a series of robustness checks (not reported in the tables to save space, but are available upon request). First, we follow Khanna and Palepu (2000b: 276) to run year-by-year regressions. Second, we employ year dummies. Third, we follow Chang and Hong (2000), who suggest an alternative scheme of dividing the entire period into three (sub)periods (1985-

\footnotetext{
${ }^{10}$ The interactions between the two continuous measures of diversification and the institutional variables are similar. Due to space constraints, we do not report these findings, which are available upon request.
} 
88, 1989-92, and 1993-96) based on their empirical exploration. The results from all these robustness checks are all qualitatively similar to those reported in the main tables and Figure 1, thus strengthening our confidence in the main findings.

\section{DISCUSSION}

\section{Contributions}

Theoretically, this article extends and supports the institution-based theory of corporate diversification, by adding a dynamic, longitudinal, and temporal component. In contrast, previous work tends to be relatively static, suggesting that conglomeration either adds or reduces value. During Korea's rapidly evolving institutional transitions, we posit and find that overall, there is indeed a discernible diversification premium during the period of 1984-96, thus strengthening the arguments on the institutional voids in emerging economies in which conglomerates may fill and add value (Khanna \& Palepu, 2000b; Peng et al., 2005). Yet, we have gone beyond these arguments by suggesting and demonstrating that such a diversification premium does not hold over time; instead, as institutional transitions unfold, it is eventually replaced by a diversification discount.

Empirically, this article makes two contributions. First, it takes a longitudinal perspective, in response to the criticism that conclusions reached by different diversification studies are "heavily influenced by their sample period" (Lang \& Stulz, 1994: 1252; Peng et al., 2005). We believe that a primary reason that most studies in emerging economies either find a diversification premium or discount is because of their relatively short sample period (in some cases only one year-see Lins \& Servaes, 2002), which may not capture enough institutional transitions. Thus, by using the longest sample period among studies in emerging economies, we are able to track how diversification premium becomes discount over time. Second, we employ three different measures of diversification, in contrast to the usual one measure which often leads to the criticism that the results are driven by the idiosyncratic measure (Robins \& Wiersema, 2003). Our results, thus, are stronger than those from single-measure studies. While previous work has documented the reduction of diversification premium (Chang \& Hong, 2000, 2002; Khanna \& Palepu, 2000b), to the best of our knowledge, our work 
represents the first empirical study that documents the longitudinal process of how a diversification premium becomes a diversification discount during institutional transitions. This is not only the first study using Korea data to have documented this transformation, but also the first such study in all emerging economies.

\section{Limitations and Future Research Directions}

Although we have sought to link the emergence of diversification discount with variables associated with institutional transitions, these are relatively simple measures that barely scratch the surface of institutional transitions. The actual mechanisms of how these changes impact firm strategies remain to be explored (Dieleman \& Sachs, 2006; Peng \& Zhou, 2005). Further, while we focus on the overall diversification premium/discount here, future work may want to explore the impact of institutional transitions on related versus unrelated diversification (Li, Ramaswamy, \& Petitt, 2006). How product diversification interacts with international diversification (Peng \& Delios, 2006) represents another fruitful avenue for future research.

Methodologically, the "chop shop" method has recently been criticized based on U.S. data. The contention centers on (1) the fact that U.S. conglomerates tend to acquire new units which are already discounted (Graham et al., 2002) and (2) the idiosyncratic nature of some widely used techniques (Whited, 2001). Since acquisitions are relatively rare in Korea (Bae at al., 2002), the first contention is probably less relevant in Korea (as well as other emerging economies). The second contention calls for more experimentation with new data and techniques. At the same time, it is important to ensure that new results are comparable with the earlier findings.

\section{CONCLUSION}

Changes in diversification premium and discount are complex. We have attempted to capture some of this complexity by leveraging the context of institutional transitions. If findings on how diversification premium becomes diversification discount from Korea converge with those from other emerging and developed economies_-albeit with different institutional nuances—our confidence in these findings may be stronger and our advice to practitioners and policymakers more assertive. In 
Korea, chaebols' conglomeration strategy, "which was optimal for their rapid growth, later inhibited their adaptation and for all practical purposes became nearly dysfunctional [prior to 1997]" (Chang, 2003a: preface). Unfortunately, from a practical and policy standpoint, our findings are at least ten years too late to be of any practical value to assist chaebols' necessary strategic change at that time. However, the practical and policy value of this research lies in the fundamental insight it reveals that an enviable diversification premium can indeed turn into a devastating diversification discount, if managers fail to make the necessary strategic changes in response to institutional and environmental transitions and if policymakers fail to push managers to initiate such changes. Chang (2003a) blames managers' and policymakers' inertia for Korea's 1997 crisis. Looking into the future, our findings can serve as a strong wake-up call to guard against such inertia that may rise again. In conclusion, if this article could contain only one message, then we would like it to be a sense of the staggering impact of institutional transitions on diversification strategies and performance outcomes.

\section{References}

Ahmadjian, C. A. 2006. Japanese business groups: Continuity in the face of change. In S.-J. Chang (ed.), Business groups in East Asia, 29-51. New York: Oxford University Press.

Bae, K., Kang, J., \& Kim, J. 2000. Tunneling or value added? Journal of Finance 57(6): 2695-2740

Berger, P., \& Ofek, E. 1995. Diversification's effect on firm value. Journal of Financial Economics 37(1): 39-66

Bertrand, M., Mehta, P., \& Mullainathan, S. 2002. Ferreting out tunneling: An application to Indian business groups. Quarterly Journal of Economics 117(1): 121-148.

Chacar, A., \& Vissa, G. 2005. Are emerging economies less efficient? Performance persistence and business group affiliation. Strategic Management Journal, 26: 933-946.

Chang, S.-J. 2003a. Financial crisis and transformation of Korean business groups. Cambridge University Press: Cambridge, UK

Chang, S.-J. 2003b. Ownership structure, expropriation, and performance of group-affiliated companies in Korea. Academy of Management Journal 46(2): 238-253.

Chang, S.-J. 2006. Business groups in East Asia: Post-crisis restructuring and new growth. Asia Pacific Journal of Management, 23: 407-417.

Chang, S.-J., \& Choi, U. 1988. Strategy, structure, and performance of Korean business groups: A transaction cost approach. Journal of Industrial Economics 37(2): 141-158

Chang, S.-J., \& Hong, J. 2000. Economic performance of group-affiliated companies in Korea: Intra-group resource sharing and internal business transactions. Academy of Management Journal 43(3): 429-448

Chang, S.-J., \& Hong, J. 2002. How much does the business group matter in Korea? Strategic Management Journal 23(3): 265-274.

Chung, H.-M. 2006. Managerial ties, control, and deregulation: An investigation of business groups entering the deregulated banking industry in Taiwan. Asia Pacific Journal of Management, 23: 505-520. 
Dieleman, M., \& Sachs, W. 2006. Oscillating between a relationship-based and a market-based model: The Salim Group. Asia Pacific Journal of Management, 23: 521-536.

Economist. 2005. South Korea. October 15: 110.

Fauver, L., Houston, J., \& Naranjo, A. 2003. Capital market development, international integration, legal systems, and the value of corporate diversification: A cross-country analysis. Journal of Financial and Quarterly Analysis 38(1): 135-157

Ferris, S., Kim, K., \& Kitsabunnarat, P. 2003. The costs (and benefits?) of diversified business groups: The case of Korean chaebols. Journal of Banking and Finance 27(2): 251-273

Graham, J., Lemmon, M., \& Wolf, J. 2002. Does corporate diversification destroy value? Journal of Finance 57: 695-720

Guillen, M. 2000. Business groups in emerging economies: A resource-based view. Academy of Management Journal 43(3): $362-380$

Hill, C., Hitt, M., \& Hoskisson, R. 1992. Cooperative versus competitive structures in related and unrelated diversified firms. Organization Science 3(4): 501-521

Hoskisson, R., Cannella, A., Thanyi, L., \& Faraci, R. 2004. Asset restructuring and business group affiliation in French civil law countries. Strategic Management Journal 25(6): 525-539

IMF (International Monetary Fund). 1997. IMF concludes Article IV consultation with Korea. Press information notice 98/39. Washington: IMF.

Isobe, T., Makino, S., \& Goerzen, A. 2006. Japanese horizontal keiretsu and the performance implications of membership. Asia Pacific Journal of Management, 23: 453-466.

Joh, S. 2003. Corporate governance and firm profitability: Evidence from Korea before the economic crisis. Journal of Financial Economics 68: 287-322

Jones, G., \& Hill, C. 1988. Transaction cost analysis of strategy-structure choice. Strategic Management Journal 9: 159-172.

Kedia, B., Mukherjee, D., \& Lahiri, S. 2006. Indian business groups: Evolution and transformation. Asia Pacific Journal of Management, 23: 559-577.

Keister, L. 2000. Chinese business groups. Oxford University Press: Oxford

Khanna, T., \& Palepu, K. 2000a. Is group affiliation profitable in emerging markets? An analysis of diversified Indian business groups. Journal of Finance 55(2): 867-891.

Khanna, T., \& Palepu, K. 2000b. The future of business groups in emerging markets: Long-run evidence from Chile. The Academy of Management Journal 43(3): 268-285.

Khanna, T., Palepu, K., \& Sinha, J. 2005. Strategies that fit emerging markets. Harvard Business Review June: 63-76.

Khanna, T., \& Rivkin, J. 2001. Estimating the performance of business groups in emerging markets. Strategic Management Jounal 22(1): 45-74

Kim, H., Hoskisson, R., Tihanyi, L., \& Hong, J. 2004. The evolution and restructuring of diversified business groups in emerging markets: The lessons from chaebols in Korea. Asia Pacific Journal of Management 21(1): 25-48

King, R., \& Levine, R. 1993. Finance and growth: Schumpeter might be right. Quarterly Journal of Economics 108(3): 717737

Kogut B., Walker, G., \& Anand, J. 2002. Agency and institutions: Organizational form and national contingency in diversification behavior. Organization Science 13(2): 162-178

La Porta, R., Lopez-de-Silanes, F., Shleifer, A., \& Vishny, R. 1997. Legal determinants of external finance. Journal of Finance 52: 1131-1150

Lang, L., \& Stulz, R. 1994. Tobin's q, corporate diversification, and firm performance. Journal of Political Economy 102: 1248-1280

Lee, C., Lee, K., \& Lee, K. 2002. Chaebols, financial liberalization, and crisis in Korea: Transformation of the quasi-internal organization. Asian Economic Journal 16(1): 17-35 
Lee, D. G., \& Lee, K. B. 2002. The dark side of internal capital allocation. Seoul Journal of Economics 15(2): 321-368

Lee, K. 2002. Corporate governance and restructuring in Korea: Before and after the crisis. In U Haley, F Richter (Eds.), Asian post-crisis management: 252-280. Palgrave: London

Lee, K., Ryu, K, \& Yoon, J. 2002. Long term performance of the business groups: The case of chaebols in Korea, paper presented at the International Conference on Corporate Governance in Asia: Korea University.

Lee, S.-H., \& Oh, K. 2007. Corruption in Asia: Pervasiveness and arbitrariness. Asia Pacific Journal of Management, 24(1): 97-114.

Leibeskind, J. 2000. Internal capital markets: Benefits, costs, and organizational arrangements. Organization Science, 11(1): 58-76.

Levine, R. 1997. Financial development and economic growth. Journal of Economic Literature 35(2): 688-726

Li, M., Ramaswamy, K., \& Petitt, B. 2006. Business groups and market failures: A focus on vertical and horizontal strategies. Asia Pacific Journal of Management, 23: 439-452.

Li, M., \& Wong, Y. 2003. Diversification and economic performance: An empirical assessment of Chinese firms. Asia Pacific Journal of Management 20(3): 243-265.

Lincoln, J., Gerlach, M., \& Ahmadjian, C. 1996. Keiretsu networks and corporate performance in Japan. American Sociological Review, 61: 67-88.

Lins, K., \& Servaes, H. 2002. Is corporate diversification beneficial in emerging markets? Financial Management 31: 5-31

Lu, Y., \& Yao, J. 2006. Impact of state ownership and control mechanisms on the performance of group affiliated companies in China. Asia Pacific Journal of Management, 23: 485-503.

Ma, X., Yao, X., \& Xi, Y. 2006. Business group affiliation and firm performance in a transition economy: A focus on ownership voids. Asia Pacific Journal of Management, 23: 467-483.

Matsusaka, J. 1993. Takeover motives during the conglomerate merger wave. Rand Journal of Economics 24(3): 357-379

Mayer, M., \& Whittington, R. 2003. Diversification in context: A cross-national and cross-temporal extension. Strategic Management Journal 24(9): 773-781.

Mursitama, T. N. 2006. Creating relational rents: The effect of business groups on affiliated firms' performance in Indonesia. Asia Pacific Journal of Management, 23: 537-557.

Nachum, L. 2004. Geographic and industrial diversification of developing country firms. Journal of Management Studies 41(2): 273-294

North, D. 1990. Institutions, institutional change, and economic performance. Norton: New York

Palepu, K. 1985. Diversification strategy, profit performance, and the entropy measure. Strategic Management Journal 6(3): 239-255

Palich, L., Cardinal, L., \& Miller, C. 2000. Curvelinearity in the diversification-performance linkage: An examination of over three decades of research. Strategic Management Journal 21(2): 155-174

Peng, M. W. 2003. Institutional transitions and strategic choices. Academy of Management Review 28(2): 275-296

Peng, M. W., \& Delios, A. 2006. What determines the scope of the firm over time and around the world? An Asia Pacific perspective. Asia Pacific Journal of Management, 23 (4): 385-405.

Peng, M. W., \& Heath, P. 1996. The growth of the firm in planned economies in transition: Institutions, organizations, and strategic choice. Academy of Management Review, 21 (2): 492-528.

Peng, M. W., Lee, S.-H., \& Wang, D. 2004. What determines the scope of the firm over time? A focus on institutional relatedness. Academy of Management Review, 30 (2): 622-633.

Peng, M. W., Wang, D., \& Jiang, Y. 2008. An institution-based view of international business strategy: A focus on emerging economies. Journal of International Business Studies (in press). 
Peng, M. W., \& Zhou, J. Q. 2005. How network strategies and institutional transitions evolve in Asia. Asia Pacific Journal of Management, 22 (4): 321-336.

Rajagopalan, N., \& Spreitzer, G. 1996. Toward a theory of strategic change. Academy of Management Review, 22: 48-79.

Ramaswamy, K., Li, M., \& Petitt, B. 2005. Who drives unrelated diversification? A study of Indian manufacturing firms. Asia Pacific Journal of Management, 21: 403-423.

Robins, J., \& Wiersema, M. 2003. The measurement of corporate portfolio strategy. Strategic Management Journal, 24(1): 39-59.

Rumelt, R. 1974. Strategy, structure, and economic performance. Harvard Business School Press: Boston

Toulan, O. 2002. The impact of market liberalization on vertical scope: The case of Argentina. Strategic Management Journal 23(6): 551-560

Ungson, G., Steers, R., \& Park, S. 1997. Korean enterprise. Boston: Harvard Business School Press.

Wan, W. 2005. Country resource environments, firm capabilities, and corporate diversification strategies. Journal of Management Studies, 42(1): 161-182.

Wan, W., \& Hoskisson, R. 2003. Home country environments, corporate diversification strategies, and firm performance. Academy of Management Journal, 46(1): 27-45

Whited, T. 2001. Is it inefficient investment that causes the diversification discount? Journal of Finance 56(5): 1667-1691

Wright, M., Filatotchev, I., Hoskisson, R., \& Peng, M. W. 2005. Strategy research in emerging economies: Challenging the conventional wisdom. Journal of Management Studies, 42 (1): 1-33.

Yiu, D., Bruton, G., \& Lu, Y. 2005. Understanding business group performance in an emerging economy: Acquiring resources and capabilities in order to prosper. Journal of Management Studies 42(1): 183-206.

Yoshikawa, T., \& McGuire, J. 2008. Change and continuity in Japanese corporate governance. Asia Pacific Journal of Management (in press). 
Table 1. Institutional transitions in the South Korean economy (1984-96)

Panel A. Transitions in product and labor markets

\begin{tabular}{|c|c|c|c|c|c|c|c|c|c|c|c|c|c|}
\hline & 1984 & 1985 & 1986 & 1987 & 1988 & 1989 & 1990 & 1991 & 1992 & 1993 & 1994 & 1995 & 1996 \\
\hline GDP growth (\%) & 8.2 & 6.5 & 11.0 & 11.0 & 10.5 & 6.1 & 9.0 & 9.2 & 5.4 & 5.5 & 8.3 & 8.9 & 6.8 \\
\hline Import liberalization ratio $(\%)^{1}$ & 84.8 & 87.7 & 91.5 & 93.6 & 94.7 & 94.7 & 96.3 & 97.2 & 97.7 & 98.1 & 98.6 & 99.0 & 99.3 \\
\hline Secondary school enrollment $(\%)^{2}$ & 86.7 & 88.8 & 88.7 & 86.8 & 89.0 & 90.8 & 91.4 & 94.0 & 96.0 & 95.3 & 97.5 & 96.5 & 98.7 \\
\hline
\end{tabular}

\section{Panel B. Transitions in capital markets}

\begin{tabular}{|c|c|c|c|c|c|c|c|c|c|c|c|c|c|}
\hline & 1984 & 1985 & 1986 & 1987 & 1988 & 1989 & 1990 & 1991 & 1992 & 1993 & 1994 & 1995 & 1996 \\
\hline Stock market capitalization/GDP (\%) & 3.3 & 3.9 & 6.4 & 12.7 & 28.3 & 39.5 & 30.0 & 25.4 & 27.9 & 35.2 & 43.6 & 37.4 & 29.1 \\
\hline Bond value/GDP $(\%)^{3}$ & 7.5 & 9.1 & 9.2 & 9.1 & 9.0 & 11.0 & 13.5 & 14.5 & 14.4 & 14.4 & 14.8 & 16.2 & 18.2 \\
\hline Private credit/GDP $(\%)^{4}$ & 84.7 & 93.1 & 90.2 & 90.3 & 91.2 & 105.8 & 113.6 & 117.3 & 121.9 & 127.2 & 137.2 & 140.2 & 150.2 \\
\hline Number of listed firms & 336 & 342 & 355 & 389 & 502 & 626 & 669 & 686 & 688 & 693 & 699 & 712 & 760 \\
\hline Number of securities firms & 25 & 25 & 25 & 25 & 25 & 25 & 25 & 31 & 32 & 32 & 32 & 33 & 38 \\
\hline Maximum foreign equity (\%) & 0 & 0 & 0 & 0 & 0 & 0 & 0 & 0 & 10 & 10 & 12 & 15 & 20 \\
\hline Daily fluctuation band $(\%)^{5}$ & 2.9 & 2.9 & 3.9 & 3.9 & 3.9 & 39 & 3.9 & 3.9 & 3.9 & 4.6 & 4.6 & 6 & 8 \\
\hline
\end{tabular}

Panel C. Changes in the average scope of the top 30 chaebol groups

\begin{tabular}{|c|c|c|c|c|c|c|c|c|c|c|c|c|c|}
\hline & 1984 & 1985 & 1986 & 1987 & 1988 & 1989 & 1990 & 1991 & 1992 & 1993 & 1994 & 1995 & 1996 \\
\hline \# of & --- & --- & --- & 16.7 & 16.8 & 17.1 & 17.9 & 18.7 & 19.1 & 20.1 & 20.5 & 20.8 & 22.3 \\
\hline$\#$ of listed affiliates & 3.29 & 3.25 & 3.21 & 3.45 & 3.89 & 4.41 & 4.47 & 4.59 & 4.55 & 4.40 & 4.41 & 4.34 & 5.25 \\
\hline
\end{tabular}

Notes

1. Import liberalization ratio is the percentage of import categories not subject to trade restrictions among all import categories (e.g., Guillen, 2000, 2001).

2. Secondary school enrollment is the percentage of elementary school graduates advancing into secondary schools (e.g., Khanna and Palepu, 2000b; Levine, 1997; Wan and Hoskisson, 2003).

3. Bond value is the value of outstanding corporate bonds.

4. Private credit is the sum of total credit given to the private sector.

5. Daily fluctuation band, which is the average value for the different ranges of stock prices, is the maximum range of stock fluctuation, beyond which the securities authorities will intervene on behalf of the government (usually by suspending trading of certain stocks).

6. The number of affiliated firms (both listed and non-listed) for the top 30 chaebols during $1984-86$ is not available, because only since 1987 has the KFTC started to disclose this information. The information on the number of listed affiliates during 1984-96 is available from the Korea Stock Exchange.

Sources: Korea Stock Exchange, Financial Supervisory Service, Korean Fair Trade Commission, and Bank of Korea. 
Table 2. Organizational demographics and excess values for stand-alone and group-affiliated firms

\begin{tabular}{|c|c|c|c|c|c|c|}
\hline & \multicolumn{2}{|c|}{$\begin{array}{c}\text { (1) Stand-alone } \\
\text { firms }\end{array}$} & \multicolumn{2}{|c|}{$\begin{array}{c}\text { (2) Group-affiliated } \\
\text { firms }\end{array}$} & \multicolumn{2}{|c|}{ Difference (2-1) } \\
\hline & Median & Mean & Median & Mean & Median $^{5}$ & Mean6 \\
\hline \multicolumn{7}{|l|}{$\begin{array}{l}\text { Panel A: Organiza- } \\
\text { tional demographics }\end{array}$} \\
\hline Capital (billion won) ${ }^{1}$ & 67 & 125 & 191 & 400 & $124 * * *$ & $275 * * *$ \\
\hline Sales (billion won) & 41 & 72 & 99 & 230 & $58 * * *$ & $158 * * *$ \\
\hline Leverage $^{2}$ & 2.035 & 2.871 & 2.624 & 4.024 & $0.589 * * *$ & $1.153 * *$ \\
\hline Capital expend./sales ${ }^{3}$ & 0.019 & 0.052 & 0.029 & 0.076 & $0.010 * * *$ & $0.022 * * *$ \\
\hline Tax/sales & 0.012 & 0.018 & 0.009 & 0.014 & $-0.004 * * *$ & $-0.004 * * *$ \\
\hline \multicolumn{7}{|l|}{$\begin{array}{l}\text { Panel B: } \\
\text { Excess values }^{4}\end{array}$} \\
\hline Using sales multiplier & 0.000 & 0.018 & 0.012 & 0.032 & 0.012 & 0.014 \\
\hline Using EBIT multiplier & 0.000 & 0.010 & 0.051 & 0.066 & $0.051 * * *$ & $0.056 * * *$ \\
\hline
\end{tabular}

Notes :

1. Capital is the sum of the book value of debt and the market value of equity.

2. Leverage is the ratio of debt to equity assets.

3. Capital expenditure is the increase in tangible assets.

4. Excess value is the natural log of the ratio of a firm's actual value to its imputed value. A positive excess value of group-affiliated companies indicates that group affiliation (or group-level diversification) enhances the value of a firm beyond that of its stand-alone peers - in other words, a diversification premium. A negative excess value indicates a diversification discount.

5. The median difference test is the Mann-Whitney test.

6. The mean difference test is the $t$-test.

$* p<0.05 ; * *<<0.01 ; * * * p<0.001$ 
Table 3: Basic statistics and correlations matrix ${ }^{1}$

\begin{tabular}{|c|c|c|c|c|c|c|c|c|c|c|c|c|c|c|c|}
\hline & $\begin{array}{c}1 . \\
\text { Excess } \\
\text { Value } \\
\text { (sales) }\end{array}$ & $\begin{array}{c}2 . \\
\text { Excess } \\
\text { value } \\
\text { (EBIT) }\end{array}$ & $\begin{array}{c}3 . \\
\text { Group } \\
\text { affiliation } \\
\text { dummy }\end{array}$ & $\begin{array}{c}4 . \\
\text { Number } \\
\text { of affiliates }\end{array}$ & $\begin{array}{c}5 . \\
\text { Entropy } \\
\text { index }\end{array}$ & $\begin{array}{c}6 . \\
\text { Firm size: } \\
\text { Sales log }\end{array}$ & $\begin{array}{l}7 . \\
\text { Profitability: } \\
\text { EBIT/ } \\
\text { sales }\end{array}$ & $\begin{array}{l}8 . \\
\text { Growth: } \\
\text { Capital/ } \\
\text { sales }\end{array}$ & $\begin{array}{c}9 \\
\text { Leverage: } \\
\text { Debt/ } \\
\text { equity }\end{array}$ & $\begin{array}{c}10 \\
\text { Firm age }\end{array}$ & $\begin{array}{c}11 . \\
\text { Stock } \\
\text { market } \\
\text { capitalization/ } \\
\text { GDP }\end{array}$ & $\begin{array}{l}12 . \\
\text { Bond } \\
\text { value/ } \\
\text { GDP }\end{array}$ & $\begin{array}{l}13 . \\
\text { Private } \\
\text { credit// } \\
\text { GDP }\end{array}$ & $\begin{array}{l}14 . \\
\text { Import } \\
\text { libera- } \\
\text { lization }\end{array}$ & $\begin{array}{c}15 . \\
\text { Secon- } \\
\text { dary } \\
\text { enrollm } \\
\text { ent }\end{array}$ \\
\hline Mean & 0.02 & 0.04 & 0.41 & 1.95 & 0.28 & 17.89 & 0.10 & 0.06 & 3.37 & 24.07 & 0.25 & 0.12 & 1.13 & 94.86 & 92.32 \\
\hline S.D. & 0.43 & 0.42 & 0.49 & 2.17 & 0.52 & 1.31 & 0.10 & 0.16 & 18.36 & 12.28 & 0.13 & 0.03 & 0.21 & 4.32 & 4.04 \\
\hline 1 & & & & & & & & & & & & & & & \\
\hline 2 & $0.4142 * * *$ & & & & & & & & & & & & & & \\
\hline 3 & 0.0159 & $0.0666 * * *$ & & & & & & & & & & & & & \\
\hline 4 & 0.0024 & $0.0786 * * *$ & $0.5273^{* * * *}$ & & & & & & & & & & & & \\
\hline 5 & 0.0076 & $0.0818 * * *$ & $0.6384 * * * *$ & $0.9285^{* * *}$ & & & & & & & & & & & \\
\hline 6 & $-0.1499^{* * * *}$ & -0.0056 & $0.3382 * * *$ & $0.3376 * * *$ & $0.3736 * * *$ & & & & & & & & & & \\
\hline 7 & $0.2245^{* * *}$ & $-0.3492 * * *$ & -0.0127 & $-0.0495^{* * * *}$ & $-0.0410^{* * * *}$ & $-0.0669 * * * *$ & & & & & & & & & \\
\hline 8 & $0.2441^{* * *}$ & $0.1666 * * *$ & $0.0724 * * * *$ & $0.0452^{* * * *}$ & $0.0420^{* * * * *}$ & 0.0141 & -0.0480 *** & & & & & & & & \\
\hline 9 & $0.0463 * * *$ & $0.0304 *$ & $0.0311^{* * *}$ & $0.0225 *$ & $0.0225^{*}$ & 0.0195 & 0.0004 & $-0.0305 *$ & & & & & & & \\
\hline 10 & $-0.0340^{* * *}$ & $-0.0540^{* * * *}$ & $0.0660 * * *$ & $0.1367 * * *$ & $0.1704 * * *$ & 0.2656 **** & 0.0223 & -0.0142 & -0.0013 & & & & & & \\
\hline 11 & -0.0091 & -0.0117 & $1.001 \mathrm{E}-16$ & $0.1024^{* * * *}$ & $0.1378 * * *$ & 0.1440 **** & 0.0158 & $0.0329^{* * *}$ & $-0.0364 * * * *$ & $0.2318 * * * *$ & & & & & \\
\hline 12 & $-0.0468 * * *$ & $-0.0312 *$ & -0.0001 & $0.1217^{* * * *}$ & $0.1528 * * *$ & 0.0128 & -0.0049 & 0.0158 & -0.0138 & $0.2803 * * *$ & $0.7008^{* * * *}$ & & & & \\
\hline 13 & $-0.0472 * * * *$ & $-0.0312^{*}$ & -0.0001 & $0.1162^{* * * *}$ & 0.1479 *** & $0.0256^{*}$ & -0.0099 & 0.0090 & -0.0137 & $0.2846 * * *$ & $0.7372^{* * * *}$ & $0.9787 * * * *$ & & & \\
\hline 14 & -0.0204 & -0.0140 & $8.236 \mathrm{E}-17$ & $0.1136^{* * * *}$ & $0.1466 * * *$ & $0.0695 * * *$ & 0.0074 & 0.0181 & $-0.0248^{*}$ & $0.2643 * * *$ & $0.8505^{* * * *}$ & $0.8644^{* * * * *}$ & $0.8353 * * * *$ & & \\
\hline 15 & $-0.0461 * * * *$ & -0.0265 & -0.0001 & $0.1122 * * * *$ & 0.1457 **** & 0.0489 **** & -0.0041 & 0.0114 & -0.0101 & $0.2793 * * *$ & $0.7327^{* * * *}$ & $0.9601 * * *$ & $0.9755^{* * * *}$ & $0.8354 * * *$ & \\
\hline
\end{tabular}

Notes: 1 . Sample sizes vary from 5117 to 7871 .

$* p<0.05 ; * * p<0.01 ; * * * p<0.001$ 
Table 4. The determinants of excess value based on the group affiliation dummy ${ }^{1}$

\begin{tabular}{|c|c|c|c|c|c|c|c|c|}
\hline \multirow{2}{*}{\begin{tabular}{|l|}
$\begin{array}{l}\text { Dependent } \\
\text { variables }\end{array}$ \\
Model
\end{tabular}} & \multicolumn{4}{|c|}{$\begin{array}{c}\text { Excess value based on the } \\
\text { sales multiplier }(N=5,213)\end{array}$} & \multicolumn{4}{|c|}{$\begin{array}{c}\text { Excess value based on the } \\
\text { EBIT multiplier }(N=5,107)\end{array}$} \\
\hline & (1) & (2) & (3) & (4) & (5) & (6) & (7) & (8) \\
\hline $\begin{array}{l}\text { Group affiliation } \\
\text { Dummy }\end{array}$ & & $\begin{array}{c}0.047 * * * \\
(4.171)\end{array}$ & $\begin{array}{c}0.046 * * * \\
(4.099)\end{array}$ & $\begin{array}{c}0.193 * * * \\
(7.587)\end{array}$ & & $\begin{array}{c}0.053 * * * \\
(4.577)\end{array}$ & $\begin{array}{l}0.053 * * * \\
(4.533)\end{array}$ & $\begin{array}{c}0.179 * * * \\
(6.860)\end{array}$ \\
\hline Time & & & $\begin{array}{c}-0.004 * * \\
(-2.629)\end{array}$ & $\begin{array}{l}0.0005^{*} \\
(2.481)\end{array}$ & & & $\begin{array}{c}-0.002 \\
(-1.551)\end{array}$ & $\begin{array}{l}0.005^{* *} \\
(2.571)\end{array}$ \\
\hline Time x Dummy & & & & $\begin{array}{c}-0.018 * * * \\
(-6.430)\end{array}$ & & & & $\begin{array}{c}-0.016 * * * \\
(-5.402)\end{array}$ \\
\hline $\begin{array}{l}\text { Firm size: } \log \\
\text { (sales) }\end{array}$ & $\begin{array}{c}-0.062 * * * \\
(-13.940)\end{array}$ & $\begin{array}{l}-0.070 * * * \\
(-14.871)\end{array}$ & $\begin{array}{l}-0.071 * * * \\
(-15.035)\end{array}$ & $\begin{array}{c}-0.071 * * * \\
(-15.050)\end{array}$ & $\begin{array}{c}-0.029 * * * \\
(-6.396)\end{array}$ & $\begin{array}{c}-0.038 * * * \\
(-7.810)\end{array}$ & $\begin{array}{l}-0.039 * * * \\
(-7.899)\end{array}$ & $\begin{array}{c}-0.039 * * * \\
(-7.886)\end{array}$ \\
\hline $\begin{array}{l}\text { Profitability: } \\
\text { EBIT/sales }\end{array}$ & $\begin{array}{l}2.071 * * * \\
(23.622)\end{array}$ & $\begin{array}{l}2.061 * * * \\
(23.582)\end{array}$ & $\begin{array}{l}2.054 * * * \\
(23.505)\end{array}$ & $\begin{array}{l}2.040 * * * \\
(23.434)\end{array}$ & $\begin{array}{l}-2.712 * * * \\
(-29.827)\end{array}$ & $\begin{array}{l}-2.718 * * * \\
(-29.978)\end{array}$ & $\begin{array}{l}-2.720 * * * \\
(-30.002)\end{array}$ & $\begin{array}{l}-2.728 * * * \\
(-30.168)\end{array}$ \\
\hline $\begin{array}{l}\text { Growth: Ca- } \\
\text { pital/sales }\end{array}$ & $\begin{array}{l}0.787 * * * \\
(19.707)\end{array}$ & $\begin{array}{l}0.779 * * * \\
(19.540)\end{array}$ & $\begin{array}{c}0.778 * * * \\
(19.527)\end{array}$ & $\begin{array}{l}0.786 * * * \\
(19.795)\end{array}$ & $\begin{array}{c}0.525 * * * \\
(13.164)\end{array}$ & $\begin{array}{l}0.519 * * * \\
(13.003)\end{array}$ & $\begin{array}{l}0.518 * * * \\
(12.999)\end{array}$ & $\begin{array}{r}0.523 * * * \\
(13.162)\end{array}$ \\
\hline $\begin{array}{l}\text { Leverage: } \\
\text { Debt/equity }\end{array}$ & $\begin{array}{l}0.002 * * * \\
(6.009)\end{array}$ & $\begin{array}{l}0.002 * * * \\
(5.871)\end{array}$ & $\begin{array}{l}0.002 * * * \\
(5.845)\end{array}$ & $\begin{array}{l}0.002 * * * \\
(5.980)\end{array}$ & $\begin{array}{l}0.002 * * * \\
(4.804)\end{array}$ & $\begin{array}{l}0.002 * * * \\
(4.692)\end{array}$ & $\begin{array}{l}0.002 * * * \\
(4.669)\end{array}$ & $\begin{array}{l}0.002 * * * \\
(4.756)\end{array}$ \\
\hline Firm age & $\begin{array}{l}-0.001^{*} \\
(-2.012)\end{array}$ & $\begin{array}{l}-0.001 \\
(-0.988)\end{array}$ & $\begin{array}{c}-0.000 \\
(-0.532)\end{array}$ & $\begin{array}{l}-0.000 \\
(-0.445)\end{array}$ & $\begin{array}{c}-0.002 * * * \\
(-3.914)\end{array}$ & $\begin{array}{c}-0.002 * * \\
(-3.207)\end{array}$ & $\begin{array}{l}-0.001 * * \\
(-2.910)\end{array}$ & $\begin{array}{c}-0.001 * * \\
(-2.838)\end{array}$ \\
\hline$R^{2}$ & 0.2276 & 0.2326 & 0.2336 & 0.2397 & 0.2009 & 0.2057 & 0.2060 & 0.2106 \\
\hline Adjusted $R^{2}$ & 0.2221 & 0.2269 & 0.2278 & 0.2338 & 0.1950 & 0.1997 & 0.1999 & 0.2043 \\
\hline$F$ & $41.173 * * *$ & $41.139 * * *$ & $40.308 * * *$ & $40.641 * * *$ & $34.396^{* * *}$ & $34.420 * * *$ & $33.609 * * *$ & $33.681 * * *$ \\
\hline
\end{tabular}

Note: $1 . t$-values are in the parentheses, 32 industry dummies are included.

$* p<0.05 ; * * p<0.01 ; * * * p<0.001$ 
Table 5. Period-by-period estimation based on the group affiliation dummy ${ }^{1}$

Panel A. Using the sales-based excess value as the dependent variable

\begin{tabular}{|l|c|c|c|c|}
\hline & $\mathbf{( 1 )}$ & $\mathbf{( 2 )}$ & $\mathbf{( 3 )}$ & $\mathbf{( 4 )}$ \\
Model & $\mathbf{1 9 8 4 - 8 7}$ & $\mathbf{1 9 8 8 - 9 0}$ & $\mathbf{1 9 9 1 - 9 3}$ & $\mathbf{1 9 9 4 - 9 6}$ \\
\hline Group affiliation & $0.107^{* * *}$ & $0.084^{* * *}$ & $0.059^{* *}$ & $-0.055^{* *}$ \\
dummy & $(3.85)$ & $(4.152)$ & $(2.915)$ & $(-2.496)$ \\
\hline Firm size: Log (sales) & $-0.027^{*}$ & $-0.065^{* * *}$ & $-0.042^{* * * *}$ & $-0.063^{* * *}$ \\
& $(-2.075)$ & $(-6.892)$ & $(-4.624)$ & $(-8.635)$ \\
\hline Profitability: & $2.875^{* * *}$ & $1.827^{* * *}$ & $1.444^{* * *}$ & $2.546^{* * *}$ \\
EBIT/sales & $(9.955)$ & $(11.047)$ & $(11.795)$ & $(14.230)$ \\
\hline Growth: Capital & $0.712^{* * *}$ & $1.026^{* * *}$ & $0.890^{* * *}$ & $0.520^{* * *}$ \\
expenditure/sales & $(6.206)$ & $(12.986)$ & $(14.045)$ & $(6.504)$ \\
\hline Leverage: Debt/ & $0.005^{* * *}$ & $0.017 * * *$ & $0.001^{* * * *}$ & $0.008^{* * *}$ \\
equity ratio & $(3.610)$ & $(5.118)$ & $(4.479)$ & $(3.712)$ \\
\hline Firm age & -0.000 & -0.000 & -0.000 & -0.000 \\
& $(-0.056)$ & $(-0.462)$ & $(-0.965)$ & $(-0.233)$ \\
\hline $\boldsymbol{R}^{2}$ & 0.1604 & 0.2394 & 0.2216 & 0.2059 \\
\hline Adjusted $\boldsymbol{R}^{\mathbf{2}}$ & 0.1553 & 0.2360 & 0.2182 & 0.2026 \\
\hline $\boldsymbol{F}$ & $30.896^{* * *}$ & $70.104 * * *$ & $67.026^{* * *}$ & $62.658^{* * *}$ \\
\hline $\boldsymbol{N}$ & 977 & 1343 & 1420 & 1457 \\
\hline
\end{tabular}

Panel B. Using the EBIT-based excess value as the dependent variable

\begin{tabular}{|l|c|c|c|c|}
\hline & $\mathbf{( 5 )}$ & $\mathbf{( 6 )}$ & $\mathbf{( 7 )}$ & $\mathbf{( 8 )}$ \\
Model & $\mathbf{1 9 8 4 - 8 7}$ & $\mathbf{1 9 8 8 - 9 0}$ & $\mathbf{1 9 9 1 - 9 3}$ & $\mathbf{1 9 9 4 - 9 6}$ \\
\hline Group affiliation & $0.106^{* * *}$ & $0.095^{* * *}$ & $0.056^{* *}$ & -0.024 \\
dummy & $(3.972)$ & $(4.166)$ & $(2.808)$ & $(-1.108)$ \\
\hline Firm size: Log (sales) & -0.022 & $-0.039^{* * * *}$ & $-0.038^{* * *}$ & $-0.039^{* * *}$ \\
& $(-1.748)$ & $(-3.692)$ & $(-4.257)$ & $(-5.346)$ \\
\hline Profitability: & $-3.614^{* * *}$ & $-1.230^{* * *}$ & $-3.726^{* * *}$ & $-3.518^{* * *}$ \\
EBIT/sales & $(-12.948)$ & $(-9.453)$ & $(-23.137)$ & $(-16.133)$ \\
\hline Growth: Capital & $0.683^{* * *}$ & $0.586^{* * *}$ & $0.798^{* * * *}$ & $0.453^{* * *}$ \\
expenditure/Sales & $(5.959)$ & $(7.295)$ & $(12.938)$ & $(5.649)$ \\
\hline Leverage: Debt/ & $0.005^{* * *}$ & $0.014 * * *$ & $0.005^{* * *}$ & -0.003 \\
equity ratio & $(3.689)$ & $(3.896)$ & $(3.857)$ & $(-1.034)$ \\
\hline Firm age & 0.000 & -0.001 & -0.001 & 0.000 \\
& $(0.664)$ & $(-1.453)$ & $(-0.631)$ & $(0.006)$ \\
\hline $\boldsymbol{R}^{\mathbf{2}}$ & 0.1913 & 0.1441 & 0.3242 & 0.1692 \\
\hline Adjusted $\boldsymbol{R}^{\mathbf{2}}$ & 0.1863 & 0.1402 & 0.3213 & 0.1656 \\
\hline $\boldsymbol{F}$ & $37.900^{* * *}$ & $37.180^{* * *}$ & $109.476^{* * * *}$ & $47.776^{* * *}$ \\
\hline $\boldsymbol{N}$ & 968 & 1332 & 1376 & 1415 \\
\hline
\end{tabular}

Note: $1 . t$-values are in the parentheses, 32 industry dummies are included.

$* p<0.05 ; * * p<0.01 ; * * * p<0.001$ 
Table 6. The determinants of excess value based on continuous measures of diversification ${ }^{1}$

Panel A. Using the number of affiliated companies as the measure of diversification

\begin{tabular}{|c|c|c|c|c|c|c|}
\hline \multirow{2}{*}{\begin{tabular}{|l}
$\begin{array}{l}\text { Dependent } \\
\text { variables }\end{array}$ \\
Model
\end{tabular}} & \multicolumn{3}{|c|}{$\begin{array}{l}\text { Excess value based on the } \\
\text { sales multiplier }(N=\mathbf{5 , 2 0 7})\end{array}$} & \multicolumn{3}{|c|}{$\begin{array}{l}\text { Excess value based on the } \\
\text { EBIT multiplier }(N=5,101)\end{array}$} \\
\hline & (1) & (2) & (3) & (4) & (5) & (6) \\
\hline Number of affiliates & $\begin{array}{l}0.008 * * * \\
(3.46)\end{array}$ & $\begin{array}{l}0.008 * * * \\
(3.60)\end{array}$ & $\begin{array}{l}0.038 * * * \\
(7.29)\end{array}$ & $\begin{array}{c}0.012 * * * \\
(5.00)\end{array}$ & $\begin{array}{l}0.012 * * * \\
(5.09)\end{array}$ & $\begin{array}{l}0.046 * * * \\
(8.72)\end{array}$ \\
\hline Time & & $\begin{array}{l}-0.004 * * \\
(-2.66)\end{array}$ & $\begin{array}{l}0.005^{*} \\
(2.39)\end{array}$ & & $\begin{array}{c}-0.003 \\
(-1.82)\end{array}$ & $\begin{array}{l}0.007 * * * \\
(3.58)\end{array}$ \\
\hline $\begin{array}{l}\text { Time } x \text { Number of } \\
\text { affiliates }\end{array}$ & & & $\begin{array}{c}-0.004 * * * \\
(-6.35)\end{array}$ & & & $\begin{array}{c}-0.004 * * * \\
(-7.19)\end{array}$ \\
\hline $\begin{array}{l}\text { Firm size: Log } \\
\text { (sales) }\end{array}$ & $\begin{array}{c}-0.068 * * * \\
(-14.28)\end{array}$ & $\begin{array}{l}-0.069 * * * \\
(-14.49)\end{array}$ & $\begin{array}{c}-0.070 * * * \\
(-14.71)\end{array}$ & $\begin{array}{c}-0.038 * * * \\
(-7.76)\end{array}$ & $\begin{array}{l}-0.039 * * * \\
(-7.89)\end{array}$ & $\begin{array}{l}-0.040 * * * \\
(-8.12)\end{array}$ \\
\hline $\begin{array}{l}\text { Profitability: } \\
\text { EBIT/sales }\end{array}$ & $\begin{array}{l}2.087 * * * \\
(23.80)\end{array}$ & $\begin{array}{l}2.082^{* * *} \\
(23.74)\end{array}$ & $\begin{array}{l}2.074 * * * \\
(23.74)\end{array}$ & $\begin{array}{c}-2.699 * * * \\
(-29.75)\end{array}$ & $\begin{array}{l}-2.70 * * * \\
(-29.78)\end{array}$ & $\begin{array}{c}-2.709 * * * \\
(-30.01)\end{array}$ \\
\hline $\begin{array}{l}\text { Growth: Capital } \\
\text { expenditure/sales }\end{array}$ & $\begin{array}{l}0.775^{* * * *} \\
(19.37)\end{array}$ & $\begin{array}{l}0.774 * * * \\
(19.34)\end{array}$ & $\begin{array}{l}0.776^{* * *} \\
(19.48)\end{array}$ & $\begin{array}{l}0.514 * * * \\
(12.88)\end{array}$ & $\begin{array}{l}0.513 * * * \\
(12.87)\end{array}$ & $\begin{array}{l}0.514 * * * \\
(12.95)\end{array}$ \\
\hline $\begin{array}{l}\text { Leverage: } \\
\text { Debt/equity ratio }\end{array}$ & $\begin{array}{l}0.002^{* * *} \\
(5.94)\end{array}$ & $\begin{array}{l}0.002^{* * * *} \\
(5.91)\end{array}$ & $\begin{array}{l}0.002 * * * \\
(6.01)\end{array}$ & $\begin{array}{l}0.002^{* *} \\
(4.73)\end{array}$ & $\begin{array}{l}0.002 * * * \\
(4.71)\end{array}$ & $\begin{array}{l}0.002^{* * * *} \\
(4.78)\end{array}$ \\
\hline Firm age & $\begin{array}{c}-0.001 \\
(-1.82)\end{array}$ & $\begin{array}{l}-0.001 \\
(-1.34)\end{array}$ & $\begin{array}{l}-0.001 \\
(-1.08)\end{array}$ & $\begin{array}{l}-0.002 * * * \\
(-3.63)\end{array}$ & $\begin{array}{l}-0.002 * * * \\
(-3.28)\end{array}$ & $\begin{array}{c}-0.001 * * \\
(-3.01)\end{array}$ \\
\hline$R^{2}$ & 0.2294 & 0.2305 & 0.2364 & 0.2048 & 0.2053 & 0.2134 \\
\hline Adjusted $R^{2}$ & 0.2238 & 0.2247 & 0.2305 & 0.1988 & 0.1992 & 0.2071 \\
\hline$F$ & $40.490 * * *$ & $39.680 * * *$ & $39.988 * * *$ & $34.307 * * *$ & $33.527 * * *$ & $34.310 * * *$ \\
\hline
\end{tabular}

Panel B. Using the entropy index as the measure of diversification

\begin{tabular}{|c|c|c|c|c|c|c|}
\hline \multirow{2}{*}{\begin{tabular}{|l}
$\begin{array}{l}\text { Dependent } \\
\text { variables }\end{array}$ \\
Model
\end{tabular}} & \multicolumn{3}{|c|}{$\begin{array}{l}\text { Excess value based on the } \\
\text { sales multiplier }(N=5,207)\end{array}$} & \multicolumn{3}{|c|}{$\begin{array}{l}\text { Excess value based on the } \\
\text { EBIT multiplier }(N=5,101)\end{array}$} \\
\hline & (7) & (8) & (9) & (10) & (11) & (12) \\
\hline Entropy index & $\begin{array}{l}0.040 * * * \\
(4.11)\end{array}$ & $\begin{array}{l}0.042 * * * \\
(4.31)\end{array}$ & $\begin{array}{l}0.170 * * * \\
(7.53)\end{array}$ & $\begin{array}{l}0.054 * * * \\
(5.46)\end{array}$ & $\begin{array}{l}0.056 * * * \\
(5.59)\end{array}$ & $\begin{array}{l}0.198 * * * \\
(8.61)\end{array}$ \\
\hline Time & & $\begin{array}{l}-0.004 * * \\
(-2.79)\end{array}$ & $\begin{array}{l}0.002 \\
(1.32)\end{array}$ & & $\begin{array}{l}-0.003 * \\
(-1.96)\end{array}$ & $\begin{array}{l}0.004^{*} \\
(2.35)\end{array}$ \\
\hline $\begin{array}{l}\text { Time x Entropy } \\
\text { index }\end{array}$ & & & $\begin{array}{c}-0.016 * * * \\
(-6.29)\end{array}$ & & & $\begin{array}{c}-0.018 * * * \\
(-6.85)\end{array}$ \\
\hline $\begin{array}{l}\text { Firm size: Log } \\
\text { (sales) }\end{array}$ & $\begin{array}{c}-0.069 * * * \\
(-14.48)\end{array}$ & $\begin{array}{r}-0.071 * * * \\
(-14.71)\end{array}$ & $\begin{array}{c}-0.071 * * * \\
(-14.89)\end{array}$ & $\begin{array}{c}-0.039 * * * \\
(-8.00)\end{array}$ & $\begin{array}{l}-0.040 * * * \\
(-8.16)\end{array}$ & $\begin{array}{l}-0.041 * * * \\
(-8.32)\end{array}$ \\
\hline $\begin{array}{l}\text { Profitability: } \\
\text { EBIT/sales }\end{array}$ & $\begin{array}{l}2.087 * * * \\
(23.82)\end{array}$ & $\begin{array}{l}.081 * * * \\
(23.75)\end{array}$ & $\begin{array}{l}2.072 * * * \\
(23.75)\end{array}$ & $\begin{array}{l}-2.702 * * * \\
(-29.81)\end{array}$ & $\begin{array}{l}-2.705 * * * \\
(-29.84)\end{array}$ & $\begin{array}{c}-2.711 * * * \\
(-30.04)\end{array}$ \\
\hline $\begin{array}{l}\text { Growth: Capital } \\
\text { expenditure/sales }\end{array}$ & $\begin{array}{l}0.775^{* * *} \\
(19.38)\end{array}$ & $\begin{array}{l}0.773 * * * \\
(19.36)\end{array}$ & $\begin{array}{l}0.777 * * * \\
(19.52)\end{array}$ & $\begin{array}{l}0.512 * * * \\
(12.86)\end{array}$ & $\begin{array}{l}0.512 * * * \\
(12.84)\end{array}$ & $\begin{array}{l}0.514 * * * \\
(12.97)\end{array}$ \\
\hline $\begin{array}{l}\text { Leverage: } \\
\text { Debt/equity ratio }\end{array}$ & $\begin{array}{l}0.002 * * * \\
(5.90)\end{array}$ & $\begin{array}{l}0.002 * * * \\
(5.86)\end{array}$ & $\begin{array}{l}0.002 * * * \\
(5.98)\end{array}$ & $\begin{array}{l}0.002 * * * \\
(4.68)\end{array}$ & $\begin{array}{l}0.002 * * * \\
(4.65)\end{array}$ & $\begin{array}{l}0.002 * * * \\
(4.74)\end{array}$ \\
\hline Firm age & $\begin{array}{c}-0.001 \\
(-1.74)\end{array}$ & $\begin{array}{l}-0.001 \\
(-1.24)\end{array}$ & $\begin{array}{l}-0.000 \\
(-1.01)\end{array}$ & $\begin{array}{c}-0.002 * * * \\
(-3.56)\end{array}$ & $\begin{array}{l}-0.002 * * * \\
(-3.19)\end{array}$ & $\begin{array}{c}-0.001 * * \\
(-2.96)\end{array}$ \\
\hline$R^{2}$ & 0.2302 & 0.2313 & 0.2371 & 0.2056 & 0.2062 & 0.2135 \\
\hline Adjusted $R^{2}$ & 0.2245 & 0.2255 & 0.2312 & 0.1996 & 0.2000 & 0.2072 \\
\hline$F$ & $40.659 * * *$ & $39.868 * * *$ & $40.149 * * *$ & $34.466 * * *$ & $33.700 * * *$ & $34.331 * * *$ \\
\hline
\end{tabular}

Note: 1. $t$-values are in the parentheses, 32 industry dummies are included. $* p<0.05 ; * * p<0.01 ; * * * p<0.001$ 
Table 7. Period-by-period estimation based on the number of affiliated companies ${ }^{1}$

Panel A. Using the sales-based excess value as the dependent variable

\begin{tabular}{|l|c|c|c|c|}
\hline & $\mathbf{( 1 )}$ & $\mathbf{( 2 )}$ & $\mathbf{( 3 )}$ & $\mathbf{( 4 )}$ \\
Model & $\mathbf{1 9 8 4 - 8 7}$ & $\mathbf{1 9 8 8 - 9 0}$ & $\mathbf{1 9 9 1 - 9 3}$ & $\mathbf{1 9 9 4 - 9 6}$ \\
\hline Number of affiliates & 0.011 & $0.023^{* * *}$ & $0.020^{* * *}$ & $-0.014^{* *}$ \\
& $(1.84)$ & $(5.73)$ & $(4.76)$ & $(-3.15)$ \\
\hline Firm size: Log (sales) & -0.015 & $-0.071^{* * *}$ & $-0.049^{* * * *}$ & $-0.062^{* * *}$ \\
& $(-1.18)$ & $(-7.55)$ & $(-5.34)$ & $(-8.49)$ \\
\hline Profitability: & $3.002^{* * *}$ & $1.898^{* * *}$ & $1.473^{* * *}$ & $2.515^{* * *}$ \\
EBIT/sales & $(10.35)$ & $(11.60)$ & $(12.09)$ & $(14.03)$ \\
\hline Growth: Capital & $0.719^{* * *}$ & $1.017^{* * *}$ & $0.873^{* * *}$ & $0.521^{* * *}$ \\
expenditure/sales & $(6.18)$ & $(12.96)$ & $(13.80)$ & $(6.54)$ \\
\hline Leverage: Debt/equity & $0.005^{* * *}$ & $0.017^{* * *}$ & $0.002^{* * *}$ & $0.009^{* * *}$ \\
ratio & $(3.43)$ & $(4.99)$ & $(4.64)$ & $(3.89)$ \\
\hline Firm age & -0.001 & -0.000 & -0.001 & -0.000 \\
& $(-0.70)$ & $(-0.33)$ & $(-1.04)$ & $(-0.34)$ \\
\hline $\boldsymbol{R}^{\mathbf{2}}$ & 0.1526 & 0.2489 & 0.2297 & 0.2076 \\
\hline Adjusted $\boldsymbol{R}^{\mathbf{2}}$ & 0.1474 & 0.2455 & 0.2264 & 0.2044 \\
\hline $\boldsymbol{F}$ & $29.210^{* * *}$ & $73.948^{* * *}$ & $70.355^{* * *}$ & $63.369^{* * *}$ \\
\hline $\boldsymbol{N}$ & 980 & 1346 & 1423 & 1458 \\
\hline
\end{tabular}

Panel B. Using the EBIT-based excess value as the dependent variable

\begin{tabular}{|l|c|c|c|c|}
\hline \multirow{2}{*}{ Model } & $\mathbf{( 5 )}$ & $\mathbf{( 6 )}$ & $\mathbf{( 7 )}$ & $\mathbf{( 8 )}$ \\
\hline Number of affiliates & $\mathbf{1 9 8 4 - 8 7}$ & $\mathbf{1 9 8 8 - 9 0}$ & $\mathbf{1 9 9 1 - 9 3}$ & $\mathbf{1 9 9 4 - 9 6}$ \\
& $0.021^{* * *}$ & $0.028^{* * *}$ & $0.017 * * *$ & $-0.011^{* *}$ \\
& $(3.77)$ & $(6.18)$ & $(3.96)$ & $(-2.70)$ \\
\hline Firm size: Log (sales) & -0.019 & $-0.050^{* * *}$ & $-0.042^{* * *}$ & $-0.036^{* * *}$ \\
& $(-1.52)$ & $(-4.71)$ & $(-4.65)$ & $(-4.93)$ \\
\hline Profitability: & $-3.475^{* * *}$ & $-1.208^{* * *}$ & $-3.697 * * *$ & $-3.571^{* * *}$ \\
EBIT/sales & $(-12.48)$ & $(-9.52)$ & $(-23.01)$ & $(-16.30)$ \\
\hline Growth: Capital & $0.667 * * *$ & $0.597 * * *$ & $0.793 * * *$ & $0.456^{* * *}$ \\
expenditure/sales & $(5.79)$ & $(7.48)$ & $(12.90)$ & $(5.71)$ \\
\hline Leverage: Debt/equity & $0.005^{* * *}$ & $0.013^{* * *}$ & $0.001 * * *$ & -0.002 \\
ratio & $(3.47)$ & $(3.58)$ & $(4.00)$ & $(-0.75)$ \\
\hline Firm age & 0.000 & -0.001 & -0.001 & -0.000 \\
& $(0.39)$ & $(-0.59)$ & $(-0.87)$ & $(-0.21)$ \\
\hline $\boldsymbol{R}^{\mathbf{2}}$ & 0.1881 & 0.1553 & 0.3272 & 0.1718 \\
\hline Adjusted $\boldsymbol{R}^{\mathbf{2}}$ & 0.1831 & 0.1515 & 0.3242 & 0.1682 \\
\hline $\boldsymbol{F}$ & $37.228^{* * *}$ & $40.690^{* * *}$ & $111.182^{* * * *}$ & $48.698^{* * *}$ \\
\hline $\boldsymbol{N}$ & 971 & 1335 & 1379 & 1416 \\
\hline
\end{tabular}

Note: $1 . t$-values are in the parentheses, 32 industry dummies are included.

$* p<0.05 ; * * p<0.01 ; * * * p<0.001$ 
Table 8. Period-by-period estimation based on the entropy index ${ }^{1}$

Panel A. Using the sales-based excess value as the dependent variable

\begin{tabular}{|l|c|c|c|c|}
\hline & $\mathbf{( 1 )}$ & $\mathbf{( 2 )}$ & $\mathbf{( 3 )}$ & $\mathbf{( 4 )}$ \\
Model & $\mathbf{1 9 8 4 - 8 7}$ & $\mathbf{1 9 8 8 - 9 0}$ & $\mathbf{1 9 9 1 - 9 3}$ & $\mathbf{1 9 9 4 - 9 6}$ \\
\hline Entropy index & $0.070^{* *}$ & $0.088^{* * *}$ & $0.072^{* * *}$ & $-0.044^{*}$ \\
& $(2.70)$ & $(5.11)$ & $(4.34)$ & $(-2.38)$ \\
\hline Firm size: Log (sales) & -0.020 & $-0.069^{* * * *}$ & $-0.048^{* * *}$ & $-0.063^{* * *}$ \\
& $(-1.57)$ & $(-7.33)$ & $(-5.23)$ & $(-8.48)$ \\
\hline Profitability: & $2.997^{* * *}$ & $1.879^{* * *}$ & $1.465^{* * *}$ & $2.536^{* * *}$ \\
EBIT/sales & $(10.35)$ & $(11.46)$ & $(12.02)$ & $(14.15)$ \\
\hline Growth: Capital & $0.718^{* * *}$ & $1.020^{* * *}$ & $0.880^{* * *}$ & $0.515^{* * *}$ \\
expenditure/sales & $(6.20)$ & $(12.97)$ & $(13.91)$ & $(6.46)$ \\
\hline Leverage: & $0.005^{* * *}$ & $0.017^{* * *}$ & $0.001^{* * *}$ & $0.008^{* * *}$ \\
Debt/equity ratio & $(3.45)$ & $(4.98)$ & $(4.55)$ & $(3.81)$ \\
\hline Firm age & -0.001 & -0.000 & -0.001 & 0.000 \\
& $(-0.54)$ & $(-0.35)$ & $(-1.03)$ & $(-0.36)$ \\
\hline $\boldsymbol{R}^{\mathbf{2}}$ & 0.1560 & 0.2452 & 0.2276 & 0.2053 \\
\hline Adjusted $\boldsymbol{R}^{\mathbf{2}}$ & 0.1508 & 0.2418 & 0.2243 & 0.2020 \\
\hline $\boldsymbol{F}$ & $29.973^{* * *}$ & $70.502^{* * *}$ & $69.528^{* * *}$ & $62.480^{* * *}$ \\
\hline $\boldsymbol{N}$ & 980 & 1346 & 1423 & 1458 \\
\hline
\end{tabular}

Panel B. Using the EBIT-based excess value as the dependent variable

\begin{tabular}{|l|c|c|c|c|}
\hline & $\mathbf{( 5 )}$ & $\mathbf{( 6 )}$ & $\mathbf{( 7 )}$ & $\mathbf{( 8 )}$ \\
Model & $\mathbf{1 9 8 4 - 8 7}$ & $\mathbf{1 9 8 8 - 9 0}$ & $\mathbf{1 9 9 1 - 9 3}$ & $\mathbf{1 9 9 4 - 9 6}$ \\
\hline Entropy index & $0.102^{* * *}$ & $0.111^{* * *}$ & $0.058^{* * * *}$ & -0.027 \\
& $(4.19)$ & $(5.75)$ & $(3.49)$ & $(-1.46)$ \\
\hline Firm size: Log (sales) & -0.022 & $-0.049^{* * *}$ & $-0.041^{* * *}$ & $-0.038^{* * *}$ \\
& $(-1.76)$ & $(-4.61)$ & $(-4.50)$ & $(-5.12)$ \\
\hline Profitability: & $-3.489^{* * *}$ & $-1.212^{* * *}$ & $-3.705^{* * *}$ & $-3.528^{* * *}$ \\
EBIT/sales & $(-12.55)$ & $(-9.54)$ & $(-23.04)$ & $(-16.13)$ \\
\hline Growth: Capital & $0.675^{* * *}$ & $0.590^{* * *}$ & $0.796^{* * *}$ & $0.446^{* * *}$ \\
expenditure/sales & $(5.88)$ & $(7.38)$ & $(12.93)$ & $(5.58)$ \\
\hline Leverage: Debt/equity & $0.005^{* * *}$ & $0.013^{* * *}$ & $0.001^{* * *}$ & -0.003 \\
ratio & $(3.51)$ & $(3.57)$ & $(3.92)$ & $(-0.89)$ \\
\hline Firm age & 0.001 & -0.001 & -0.001 & -0.000 \\
& $(0.47)$ & $(-0.60)$ & $(-0.87)$ & $(-0.20)$ \\
\hline $\boldsymbol{R}^{\mathbf{2}}$ & 0.1908 & 0.1521 & 0.3254 & 0.1687 \\
\hline Adjusted $\boldsymbol{R}^{\mathbf{2}}$ & 0.1858 & 0.1483 & 0.3224 & 0.1652 \\
\hline $\boldsymbol{F}$ & $37.895^{* * *}$ & $39.717 * * *$ & $110.319^{* * * *}$ & $47.667 * * *$ \\
\hline $\boldsymbol{N}$ & 971 & 1335 & 1379 & 1415 \\
\hline
\end{tabular}

Note: $1 . t$-values are in the parentheses, 32 industry dummies are included. * $p<0.05 ; * * p<0.01 ; * * * p<0.001$ 
Table 9. How institutional transitions impact diversification premium/discount based on the group affiliation dummy ${ }^{1}$

Panel A. Using the sales-based excess value as dependent variable $(N=5,213)$

\begin{tabular}{|c|c|c|c|c|c|c|c|c|c|c|}
\hline Model & (1) & (2) & (3) & (4) & (5) & (6) & (7) & (8) & (9) & (10) \\
\hline $\begin{array}{l}\text { Group affiliation } \\
\text { dummy }\end{array}$ & $\begin{array}{c}0.048 * * * \\
(4.18) \\
\end{array}$ & $\begin{array}{c}0.130 * * * \\
(4.83) \\
\end{array}$ & $\begin{array}{c}0.047 * * * \\
(4.156)\end{array}$ & $\begin{array}{c}0.337 * * * \\
(7.57)\end{array}$ & $\begin{array}{l}0.047 * * * \\
(4.14) \\
\end{array}$ & $\begin{array}{c}0.469 * * * \\
(7.86) \\
\end{array}$ & $\begin{array}{c}0.046^{* * *} \\
(4.08)\end{array}$ & $\begin{array}{c}1.096^{* * *} \\
(4.14)\end{array}$ & $\begin{array}{c}0.046 * * * \\
(4.11)\end{array}$ & $\begin{array}{c}1.685^{* * *} \\
(6.86) \\
\end{array}$ \\
\hline $\begin{array}{l}\begin{array}{l}\text { Institutional } \\
\text { development }^{2}\end{array} \\
\end{array}$ & $\begin{array}{l}0.015 \\
(0.33) \\
\end{array}$ & $\begin{array}{c}0.159^{* *} \\
(2.60) \\
\end{array}$ & $\begin{array}{l}-0.588 * * * \\
(-3.50)\end{array}$ & $\begin{array}{l}0.459^{*} \\
(2.01)\end{array}$ & $\begin{array}{l}-0.077 * * \\
(-3.00) \\
\end{array}$ & $\begin{array}{c}0.092^{* *} \\
(2.66) \\
\end{array}$ & $\begin{array}{l}-0.002 \\
(-1.38) \\
\end{array}$ & $\begin{array}{l}0.004 \\
(1.83) \\
\end{array}$ & $\begin{array}{c}-0.004 * * \\
(-2.74) \\
\end{array}$ & $\begin{array}{c}0.005^{*} \\
(2.52) \\
\end{array}$ \\
\hline $\begin{array}{l}\text { Stock capitalization/ } \\
\text { GDP x group dummy }\end{array}$ & & $\begin{array}{c}-0.294 * * * \\
(-3.38)\end{array}$ & & & & & & & & \\
\hline $\begin{array}{l}\text { Bond value/GDP x } \\
\text { group dummy }\end{array}$ & & & & $\begin{array}{c}-2.211 * * * \\
(-6.74)\end{array}$ & & & & & & \\
\hline $\begin{array}{l}\text { Private credit/GDP x } \\
\text { group dummy }\end{array}$ & & & & & & $\begin{array}{c}-0.360 * * * \\
(-7.20)\end{array}$ & & & & \\
\hline $\begin{array}{l}\text { Import liberalization } \mathrm{x} \\
\text { group dummy }\end{array}$ & & & & & & & & $\begin{array}{c}-0.011 * * * \\
(-3.97)\end{array}$ & & \\
\hline $\begin{array}{l}\text { Secondary enrollment } x \\
\text { group dummy }\end{array}$ & & & & & & & & & & $\begin{array}{c}-0.018 * * * \\
(-6.68)\end{array}$ \\
\hline Firm size: $\log$ (sales) & $\begin{array}{c}-0.071^{* * * *} \\
(-14.83) \\
\end{array}$ & $\begin{array}{c}-0.071 * * * \\
(-14.90) \\
\end{array}$ & $\begin{array}{c}-0.072 * * * \\
(-15.20) \\
\end{array}$ & $\begin{array}{c}-0.072 * * * \\
(-15.17) \\
\end{array}$ & $\begin{array}{c}-0.072 * * * \\
(-15.12)\end{array}$ & $\begin{array}{c}-0.072 * * * \\
(-15.12) \\
\end{array}$ & $\begin{array}{c}-0.070 * * * \\
(-14.88)\end{array}$ & $\begin{array}{c}-0.070 * * * \\
(-14.91) \\
\end{array}$ & $\begin{array}{c}-0.071^{* * *} * \\
(-15.04) \\
\end{array}$ & $\begin{array}{c}-0.071^{* * *} * \\
(-15.06)\end{array}$ \\
\hline Profitability: EBIT/sales & $\begin{array}{c}2.061 * * * \\
(23.58) \\
\end{array}$ & $\begin{array}{c}2.056^{* * * *} \\
(23.55) \\
\end{array}$ & $\begin{array}{c}2.049 * * * \\
(23.45) \\
\end{array}$ & $\begin{array}{c}2.037 * * * \\
(23.41) \\
\end{array}$ & $\begin{array}{c}2.052^{* * * *} \\
(23.46) \\
\end{array}$ & $\begin{array}{c}2.036 * * * \\
(23.41) \\
\end{array}$ & $\begin{array}{c}2.060 * * * \\
(23.58) \\
\end{array}$ & $\begin{array}{c}2.052 * * * \\
(23.51) \\
\end{array}$ & $\begin{array}{c}2.054 * * * \\
(23.50) \\
\end{array}$ & $\begin{array}{c}2.041^{* * * *} \\
(23.45) \\
\end{array}$ \\
\hline $\begin{array}{l}\text { Growth: Capital } \\
\text { expenditure/sales }\end{array}$ & $\begin{array}{c}0.779 * * * \\
(19.54)\end{array}$ & $\begin{array}{c}0.780^{* * *} \\
(19.59)\end{array}$ & $\begin{array}{c}0.779 * * * \\
(19.56)\end{array}$ & $\begin{array}{c}0.788^{* * * *} \\
(19.87)\end{array}$ & $\begin{array}{c}0.778^{* * *} \\
(19.52)\end{array}$ & $\begin{array}{c}0.786 * * * \\
(19.82)\end{array}$ & $\begin{array}{c}0.779 * * * \\
(19.54)\end{array}$ & $\begin{array}{c}0.784 * * * \\
(19.67)\end{array}$ & $\begin{array}{c}0.778^{* * * *} \\
(19.52)\end{array}$ & $\begin{array}{c}0.786^{* * * *} \\
(19.79)\end{array}$ \\
\hline $\begin{array}{l}\text { Leverage: Debt/equity } \\
\text { ratio }\end{array}$ & $\begin{array}{c}0.002 * * * \\
(5.88) \\
\end{array}$ & $\begin{array}{c}0.002 * * * \\
(5.91) \\
\end{array}$ & $\begin{array}{l}0.002 * * * \\
(5.86) \\
\end{array}$ & $\begin{array}{c}0.002 * * * \\
(6.02)\end{array}$ & $\begin{array}{l}0.002 * * * \\
(5.858) \\
\end{array}$ & $\begin{array}{l}0.002^{* * * *} \\
(6.00)\end{array}$ & $\begin{array}{l}0.002 \text { *** } \\
(5.85) \\
\end{array}$ & $\begin{array}{l}0.002 * * * \\
(5.92)\end{array}$ & $\begin{array}{c}0.002 * * * \\
(5.86) \\
\end{array}$ & $\begin{array}{l}0.002^{* * *} \\
(6.05)\end{array}$ \\
\hline Firm age & $\begin{array}{l}-0.000 \\
(-1.01) \\
\end{array}$ & $\begin{array}{l}-0.000 \\
(-0.94) \\
\end{array}$ & $\begin{array}{c}-0.000 \\
(-0.399) \\
\end{array}$ & $\begin{array}{l}-0.000 \\
(-0.28) \\
\end{array}$ & $\begin{array}{r}-0.000 \\
(-0.458) \\
\end{array}$ & $\begin{array}{l}-0.000 \\
(-0.34) \\
\end{array}$ & $\begin{array}{l}-0.000 \\
(0.81) \\
\end{array}$ & $\begin{array}{c}-0.000 \\
(-0.76) \\
\end{array}$ & $\begin{array}{l}-0.000 \\
(-0.52) \\
\end{array}$ & $\begin{array}{c}-0.000 \\
(-0.43) \\
\end{array}$ \\
\hline$R^{2}$ & 0.2326 & 0.2343 & 0.2344 & 0.2411 & 0.2339 & 0.2416 & 0.2329 & 0.2352 & 0.2337 & 0.2403 \\
\hline Adjusted $R^{2}$ & 0.2268 & 0.2284 & 0.2286 & 0.2351 & 0.2281 & 0.2357 & 0.2271 & 0.2292 & 0.2279 & 0.2343 \\
\hline $\boldsymbol{F}$ & $40.081 * * *$ & $39.442 * * *$ & $40.486^{* * * *}$ & $40.948 * * *$ & 40.377 *** & $41.054 * * *$ & $40.140 * * *$ & $39.642 * * *$ & $40.327 * * *$ & $40.766^{* * * *}$ \\
\hline
\end{tabular}




\section{Table 9. (continued)}

Panel B. Using the EBIT-based excess value as dependent variable $(N=5,107)$

\begin{tabular}{|c|c|c|c|c|c|c|c|c|c|c|}
\hline Model & (11) & (12) & (13) & (14) & (15) & (16) & (17) & (18) & (19) & (20) \\
\hline $\begin{array}{l}\text { Group affiliation } \\
\text { dummy }\end{array}$ & $\begin{array}{c}0.055^{* * *} * \\
(4.68) \\
\end{array}$ & $\begin{array}{c}0.122 * * * \\
(4.42) \\
\end{array}$ & $\begin{array}{c}0.053 * * * \\
(4.56)\end{array}$ & $\begin{array}{c}0.311^{* * *} * \\
(6.83)\end{array}$ & $\begin{array}{c}0.053^{* * *} * \\
(4.55) \\
\end{array}$ & $\begin{array}{c}0.426 * * * \\
(6.96)\end{array}$ & $\begin{array}{l}0.054 * * * \\
(4.59) \\
\end{array}$ & $\begin{array}{c}0.899 * * * \\
(3.32) \\
\end{array}$ & $\begin{array}{l}0.053 * * * \\
(4.54)\end{array}$ & $\begin{array}{l}1.500 * * * \\
(5.95)\end{array}$ \\
\hline $\begin{array}{l}\text { Institutional } \\
\text { Development }\end{array}$ & $\begin{array}{l}0.056 \\
(1.25) \\
\end{array}$ & $\begin{array}{l}0.174 * * \\
(2.77) \\
\end{array}$ & $\begin{array}{l}-0.428^{*} \\
(-2.49) \\
\end{array}$ & $\begin{array}{l}0.508^{*} \\
(2.17) \\
\end{array}$ & $\begin{array}{r}-0.059^{*} \\
(-2.25) \\
\end{array}$ & $\begin{array}{l}0.091^{*} \\
(2.55) \\
\end{array}$ & $\begin{array}{r}0.001 \\
(0.43) \\
\end{array}$ & $\begin{array}{r}0.005^{*} \\
(2.52) \\
\end{array}$ & $\begin{array}{l}-0.002 \\
(-1.48) \\
\end{array}$ & $\begin{array}{l}0.005^{* * *} \\
(2.82) \\
\end{array}$ \\
\hline $\begin{array}{l}\text { Stock capitalization/ } \\
\text { GDP x group dummy }\end{array}$ & & $\begin{array}{l}-0.240 * * \\
(-2.69) \\
\end{array}$ & & & & & & & & \\
\hline $\begin{array}{l}\text { Bond value/GDP x } \\
\text { group dummy }\end{array}$ & & & & $\begin{array}{c}-1.973^{* * *} * \\
(-5.86)\end{array}$ & & & & & & \\
\hline $\begin{array}{l}\text { Private credit/GDP x } \\
\text { group dummy }\end{array}$ & & & & & & $\begin{array}{c}-0.319 * * * \\
(-6.21) \\
\end{array}$ & & & & \\
\hline $\begin{array}{l}\text { Import liberalization } \mathrm{x} \\
\text { group dummy }\end{array}$ & & & & & & & & $\begin{array}{c}-0.009^{* * *} \\
(-3.12)\end{array}$ & & \\
\hline $\begin{array}{l}\text { Secondary enrollment } \mathrm{x} \\
\text { group dummy }\end{array}$ & & & & & & & & & & $\begin{array}{c}-0.016 * * * \\
(-5.74) \\
\end{array}$ \\
\hline Firm size: Log (sales) & $\begin{array}{c}-0.039 * * * \\
(-7.90) \\
\end{array}$ & $\begin{array}{c}-0.039 * * * \\
(-7.94) \\
\end{array}$ & $\begin{array}{c}-0.040 * * * \\
(-8.05) \\
\end{array}$ & $\begin{array}{c}-0.039 * * * \\
(-7.99)\end{array}$ & $\begin{array}{c}-0.040 * * * \\
(-8.00)\end{array}$ & $\begin{array}{c}-0.039 * * * \\
(-7.97)\end{array}$ & $\begin{array}{c}-0.038 * * * \\
(-7.81) \\
\end{array}$ & $\begin{array}{c}-0.038 * * * \\
(-7.82) \\
\end{array}$ & $\begin{array}{c}-0.039 * * * \\
(-7.89)\end{array}$ & $\begin{array}{c}-0.039 * * * \\
(-7.88) \\
\end{array}$ \\
\hline Profitability: EBIT/sales & $\begin{array}{c}-2.722 * * * \\
(-30.00) \\
\end{array}$ & $\begin{array}{c}-2.725 * * * \\
(-30.06)\end{array}$ & $\begin{array}{c}-2.724 * * * \\
(-30.05) \\
\end{array}$ & $\begin{array}{c}-2.733 * * * \\
(-30.24) \\
\end{array}$ & $\begin{array}{c}-2.724 * * * \\
(-30.04) \\
\end{array}$ & $\begin{array}{c}-2.731 * * * \\
(-30.23) \\
\end{array}$ & $\begin{array}{c}-2.719 * * * \\
(-29.98) \\
\end{array}$ & $\begin{array}{c}-2.725 * * * \\
(-30.01) \\
\end{array}$ & $\begin{array}{c}-2.721 * * * \\
(-30.00)\end{array}$ & $\begin{array}{c}-2.727 * * * \\
(-30.17) \\
\end{array}$ \\
\hline $\begin{array}{l}\text { Growth: Capital } \\
\text { expenditure/sales }\end{array}$ & $\begin{array}{c}0.518 * * * \\
(12.99) \\
\end{array}$ & $\begin{array}{c}0.519 * * * \\
(13.02) \\
\end{array}$ & $\begin{array}{c}0.519 * * * \\
(13.02) \\
\end{array}$ & $\begin{array}{c}0.526^{* * * *} \\
(13.23) \\
\end{array}$ & $\begin{array}{c}0.518 * * * \\
(12.99) \\
\end{array}$ & $\begin{array}{c}0.524 * * * \\
(13.19) \\
\end{array}$ & $\begin{array}{c}0.518^{* * * *} \\
(13.00)\end{array}$ & $\begin{array}{c}0.521 * * * \\
(13.08) \\
\end{array}$ & $\begin{array}{c}0.518 * * * \\
(13.00) \\
\end{array}$ & $\begin{array}{c}0.523 * * * \\
(13.17) \\
\end{array}$ \\
\hline $\begin{array}{l}\text { Leverage: Debt/equity } \\
\text { ratio }\end{array}$ & $\begin{array}{l}0.002^{* * *} \\
(4.73) \\
\end{array}$ & $\begin{array}{c}0.002^{* * *} \\
(4.76) \\
\end{array}$ & $\begin{array}{l}0.002^{* * * *} \\
(4.67)\end{array}$ & $\begin{array}{l}0.002^{* * * *} \\
(4.78)\end{array}$ & $\begin{array}{c}0.002^{* * * *} \\
(4.66) \\
\end{array}$ & $\begin{array}{l}0.002^{* * * *} \\
(4.76)\end{array}$ & $\begin{array}{l}0.002^{* * * *} \\
(4.70)\end{array}$ & $\begin{array}{c}0.002 * * * \\
(4.75) \\
\end{array}$ & $\begin{array}{l}0.002 * * * \\
(4.68) \\
\end{array}$ & $\begin{array}{c}0.002^{* * *} \\
(4.82) \\
\end{array}$ \\
\hline Firm age & $\begin{array}{c}-0.002 * * * \\
(-3.27) \\
\end{array}$ & $\begin{array}{c}-0.002 * * * \\
(-3.23)\end{array}$ & $\begin{array}{l}-0.001 * * \\
(-2.76)\end{array}$ & $\begin{array}{l}-0.001^{* *} \\
(-2.66) \\
\end{array}$ & $\begin{array}{c}-0.001 * * \\
(-2.78) \\
\end{array}$ & $\begin{array}{c}-0.001 * * \\
(-2.68)\end{array}$ & $\begin{array}{l}-0.002 * * * \\
(-3.24)\end{array}$ & $\begin{array}{c}-0.002 * * * \\
(-3.20)\end{array}$ & $\begin{array}{l}-0.001 * * \\
(-2.93)\end{array}$ & $\begin{array}{l}-0.001 * * \\
(-2.84) \\
\end{array}$ \\
\hline$R^{2}$ & 0.2059 & 0.2070 & 0.2066 & 0.2120 & 0.2065 & 0.2125 & 0.2057 & 0.2072 & 0.2060 & 0.2112 \\
\hline Adjusted $R^{2}$ & 0.1998 & 0.2008 & 0.2005 & 0.2057 & 0.2003 & 0.2062 & 0.1996 & 0.2009 & 0.1999 & 0.2049 \\
\hline$F$ & $33.581 * * *$ & $32.964 * * *$ & $33.731 * * *$ & $33.964 * * *$ & $33.694 * * *$ & $34.060 * * *$ & $33.537 * * *$ & $33.000 * * *$ & $33.602 * * *$ & $33.794 * * *$ \\
\hline
\end{tabular}

Notes:

1. $t$-values are in the parentheses, 32 industry dummies are included.

2. Five institutional development measures are used: (a) stock market development for Models 1 and 2, (b) bond market development for Models 3 and 4, (c) credit market development for Models 5 and 6, (d) import market liberalization for Models 7 and 8, and (e) labor market development (secondary school enrollment) for Models 9 and 10.

$* p<0.05 ; * * p<0.01 ; * * * p<0.001$ 
Figure 1. From diversification premium to diversification discount over time
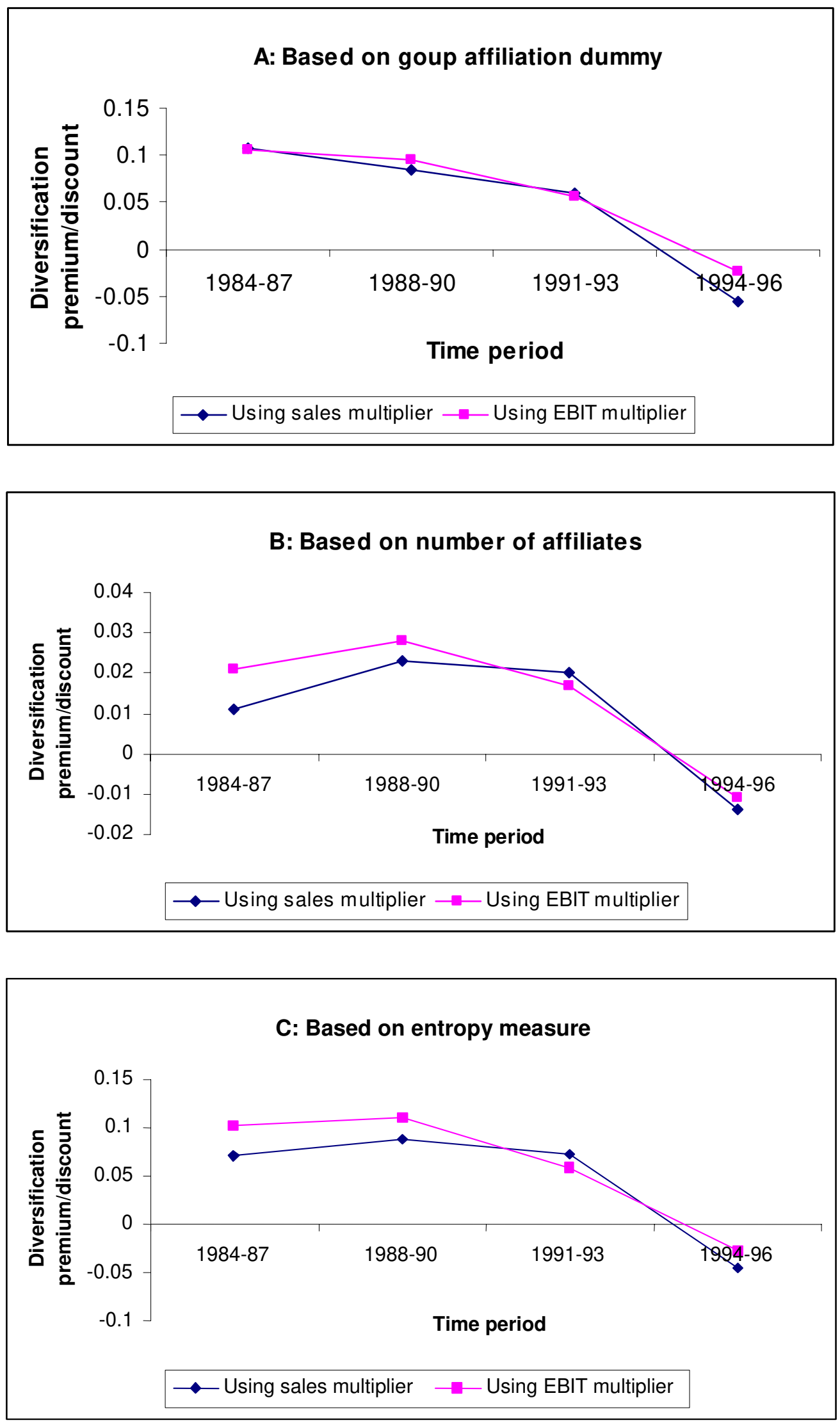